\title{
Polyphenols and their effects on diabetes management: A review
}

\author{
Naheed Aryaeian ${ }^{1 *}$, Sara Khorshidi Sedehi ${ }^{2}$, Tahereh Arablou ${ }^{2}$ \\ Received: 27 Aug 2016 \\ Published: 26 Dec 2017
}

\begin{abstract}
Background: Type 2 diabetes is a growing public health problem and is associated with increased morbidity and mortality. The worldwide prevalence of type 2 diabetes is rising. Polyphenols, such as flavonoids, phenolic acid, and stilbens, are a large and heterogeneous group of phytochemicals in plant-based foods. In this review, we aimed at assessing the studies on polyphenols and diabetes management.

Methods: A literature search in the PubMed, EMBASE, Scopus, and ISI Web of Science databases was conducted to identify relevant studies published from 1986 to Jan 2017.

Results: Several animal models and a limited number of human studies have revealed that polyphenols decrease hyperglycemia and improve acute insulin secretion and insulin sensitivity. The possible mechanisms include decrease in glucose absorption in the intestine, inhibition of carbohydrates digestion, stimulation of insulin secretion, modulation of glucose release from the liver, activation of insulin receptors and glucose uptake in insulin-sensitive tissues, modulation of intracellular signaling pathways, and gene expression.

Conclusion: Growing evidence indicates that various dietary polyphenols may influence blood glucose at different levels and may also help control and prevent diabetes complication. However, we still need more clinical trials to determine the effects of polyphenols- rich foods, their effective dose, and mechanisms of their effects in managing diabetes.
\end{abstract}

Keywords: Polyphenol, Blood glucose, Inflammation, Phytochemical, Type 2 diabetes

Copyright $\odot$ Iran University of Medical Sciences

Cite this article as: Aryaeian N, Khorshidi Sedehi S, Arablou T. Polyphenols and their effects on diabetes management: A review. Med J Islam Repub Iran. 2017 (26 Dec);31:134. https://doi.org/10.14196/mjiri.31.134

\section{Introduction}

Type 2 diabetes (T2D), a growing public health problem, is associated with increased morbidity and mortality. According to the report of International Diabetes Federation (IDF), the number of people with diabetes in the world will increase from 382 million in 2013 to 592 million by 2035 (1). In Europe, approximately $6 \%$ to $8 \%$ of the population suffer from diabetes, of them nearly $90 \%$ have T2D, making T2D the fastest enhancing disease in Europe and worldwide (2). Inflammation is a serious problem in patients with diabetes and plays an important role in the evolution of atherosclerotic process in non-insulin dependent diabetes mellitus (NIDDM), together with the known influence of glucose and lipid

Corresponding author: Dr Naheed Aryaeian, aryaeian.n@iums.ac.ir

1. Research Center for Environmental Health Technology, Iran University of Medical Sciences and Department of Nutrition, School of Public Health, Iran University of Medical Sciences, Tehran, Iran.

2. Department of Nutrition, School of Public Health, Iran University of Medical Sciences, Tehran, Iran. metabolism pathology. Inflammation both increases the levels of circulating inflammatory cytokines and insulin resistance in the liver, skeletal muscles, and vascular endothelium (3).

Polyphenols are the most abundant antioxidants in the diet of humans. There are thousands of natural polyphenols in the plant kingdom (4). Polyphenols, such as flavonoids, phenolic acid, and stilbenes, are a large and heterogeneous group of phytochemicals in plant-based foods (tea, soy, coffee, cocoa, cereal grains, cinnamon, ginger, fruits, and berries). Polyphenols are classified into several categories based on the number of phenol rings and structural elements that bind these rings (4).

$\uparrow$ What is "already known" in this topic:

This research can be used by physicians, nutritionists, and diet therapists and by all people, especially those with diabetes and those suffering from insulin resistance, such as metabolic syndrome and polycystic ovary syndrome (PCOS).

\section{$\rightarrow$ What this article adds:}

The possible effect of polyphenol on diabetes management is already known, and this article adds to the previously known knowledge by summarizing the results of other researches on the effectiveness and mechanisms of polyphenols on diabetes management. 
Growing evidence indicates that various dietary polyphenols may prevent diabetes. In this article, we will discuss some polyphenol-rich foods and their possible effect on blood glucose.

\section{Curcumin}

Curcumin is a natural compound extracted from the root of Curcuma Longa and is the main component of the Indian curry spice. Curcumin has been consumed in the traditional Asian medicine for centuries because of its anti-inflammatory properties. Curcumin has also antioxidant and anticarcinogenic effects (5-7). Its anticancer activity is mainly attributable to the inactivation of hypoxia-inducible factor-1(HIF-1), as curcumin is known to downregulate HIF-1 $\alpha$ (8) and HIF-1 $\beta$ (9) and inhibit downstream actions, e.g. angiogenesis mediated by HIF-1. Also, it is able to selectively kill tumor cells or prevent tumorigenesis through interfering with many cellular pathways $(6,10)$. It represses nuclear factor- $\kappa B$ $(\mathrm{NF}-\kappa \mathrm{B})$, inhibits adipogenic transcription factors and the cell cycle, and induces apoptosis (11-13). In colorectal cancer, curcumin treatment upregulates p53 expression (14). It has been reported that curcumin inhibits TNF- $\alpha$-induced expression of Interleukin- 1 beta (IL-1 $\beta$ ), IL-6, and tumor necrosis factor (TNF- $\alpha$ ) in human keratinocytes. It enhances the secretion of adiponectin (15), inhibits insulin-regulated glucose transporter 4 (GLUT4) translocation and glucose transport $(16,17)$. Some studies demonstrate that $10-25 \mu \mathrm{M}$ of curcumin efficiently inhibited the differentiation of mouse adipocytes. In concentrations of $10-50 \mu \mathrm{M}$, curcumin is able to activate AMP-activated protein kinase (AMPK)(18) and it can also inhibit the activation of MAPK pathway, c-Jun N-terminal kinases (JNK), p38MAPK, and extracellular signal-regulated kinases (ERK) in adipocytes (19). Thus, it stimulates proliferation (20) but suppresses lipid accumulation and adipogenesis (21). However, conflicting data on how curcumin affects peroxisome prolator-activated receptors (PPARs) ranges from direct activation to inhibition via AMPK (22-24). Interestingly, curcumin applied at a half maximal inhibitory concentration (IC50) of $45 \mu \mathrm{M}$ can also interfere with cellular energy balance by inhibiting ATP synthesis at the mitochondrial membrane (25). Furthermore, it was illustrated that active spice-derived components such as curcumin suppress obesity-induced inflammatory responses in adipose tissue of obese mice. As a result, migration and release of monocyte chemoattractant protein-1 (MCP-1) and TNF- $\alpha$ were inhibited and MCP-1 was released from adipocytes (26). Beyond the anti-inflammatory properties, curcumin has also ameliorated diabetes in different mouse models; $200 \mathrm{mg}$ curcumin/ $\mathrm{kg}$ diet has improved insulin resistance and hyperglycemia in mice. Also, it elevated insulin level and lowered the free fatty acid, triglyceride, cholesterol, and glucose level in blood and reduced lipid oxidation (27). Further studies on curcumin has illustrated that it reduces macrophage infiltration into the white adipose tissue, induces the expression of adiponectin, and decreases NF- $\kappa \mathrm{B}$ activity $(28,29)$. Administration of $500 \mathrm{mg} / \mathrm{kg}$ curcumin in diet leads to a decrease in body weight gain, adiposity, and expression of VEGF in mice (30). Antihyperlipidemic and antidiabetic effects were also seen in rats $(31,32)$ and hamsters (33). Taken together, these data indicated that curcumin can repress inflammation and obesity and improve the chronic condition in diabetes.

An in vitro study found that curcuminoids effectively enhanced the phosphorylation of AMP-activated protein kinase (AMPK) and its downstream target acetyl-CoA carboxylase (ACC) in H4IIE rat hepatoma and Hep3B human hepatoma cells with 400 times (curcumin) to 100 000 times (tetrahydrocurcuminoids) the potency of metformin. These results suggest that AMPK mediated the suppression of hepatic gluconeogenesis and may be a potential mechanism mediating glucose-lowering effects of curcuminoids (34). In another study on 240 prediabetic adults, participants were given 250 milligrams of curcumin or a placebo every day for 9 months. After intervention, none of those taking curcumin developed diabetes, but $16.4 \%$ of the placebo

Table 1. Overview of recent clinical trials testing curcumin with respect to diabetic and inflammatory markers

\begin{tabular}{ll}
\hline Treatment group & Dose; duration \\
\hline 25 T2DM patients & $200 \mathrm{mg}$ curcumin $(1000 \mathrm{mg} \mathrm{Meriva}) / \mathrm{d} ; 4$ \\
10/9 healthy participants & $500 \mathrm{mg} / 6000 \mathrm{mg}$ curcumin $/ \mathrm{d} ; 7 \mathrm{~d}$
\end{tabular}

$10 / 9$ healthy participants $\quad 500 \mathrm{mg} / 6000 \mathrm{mg}$ curcumin/d; $7 \mathrm{~d}$

20 T2DM

nephropathy patients

50 patients with

osteoarthritis

21 patients with

$\beta$-thalassemia/Hb E

$15 / 14 / 15$ patients

with ACS

$8 / 11$ healthy participants

60 T2DM patients
$66.3 \mathrm{mg}$ curcumin (1500 mg tumeric)/d; $2 \mathrm{~m}$

$200 \mathrm{mg}$ curcumin (1000 mg Meriva)/d; $8 \mathrm{~m}$

$500 \mathrm{mg}$ curcuminoids (357 mg curcumin, $107 \mathrm{mg}$ demethoxycurcumin, and $36 \mathrm{mg}$ bisdemethoxycurcumin)/d; $12 \mathrm{~m}$

45/90/180 mg curcumin (2/4/8 g curcuma extract)/d; $2 \mathrm{~m}$

$1 / 4 \mathrm{~g}$ curcumin $/ \mathrm{d} ; 6 \mathrm{~m}$

Group I received standard metformin treatment and group II metformin therapy with turmeric ( $2 \mathrm{~g})$ supplements for $4 \mathrm{w}$
(36) Improvement of diabetic microangiopathy

(37) Decline of serum cholesterol and triglyceride levels (more pronounced at the lower dose than the higher); enhancement of antioxidant capacity

(38) Attenuation of proteinuria, TGF- $\beta$ and IL-8 levels

(39) Decrease in inflammatory markers (IL-1 $\beta$, IL-6, sCD40L, sVCAM-1, ESR)

(40) Improvement of oxidative stress markers including MDA, SOD, GSH-Px, and GSH in RBCs, and NTBI in serum

(41) Trend of reduction in total cholesterol and LDL cholesterol level by low-dose curcumin

(42) No significant effect on serum cholesterol or triacylglycerol

(43) Reduction in lipid peroxidation, MDA, and enhanced total antioxidant status.

Beneficial effects on dyslipidemia and decrease in hsCRP

ACS: acute coronary syndrome; T2DM: Type 2 diabetes mellitus; $g$ : gram; d: days; $w$ : weeks; $\mathrm{m}$ : months; TGF- $\beta$ : transforming growth factor beta 1 ; IL: interleukin; sCD40L: Soluble CD40 ligand; sVCAM-1: Soluble cell adhesion molecule-1; ESR: erythrocyte sedimentation rate; MDA: Malondialdehyde; hsCRP: high sensitive Creactive protein; SOD: superoxide dismutase; GSH-Px: glutathione peroxidase; GSH: reduced glutathione; RBC: red blood cells; NTBI: non-transferrin bound iron 
group did. In other words,curcumin was $100 \%$ effective in preventing Type 2 diabetes (35). Table 1 demonstrates recent clinical trials testing curcumin with respect to diabetic and inflammatory markers.

\section{Resveratrol}

Resveratrol is a non-flavonoid polyphenol produced naturally by many plants including grapes, peanuts, cranberries, blueberries, and Japanese knotweed. The resveratrol content ranges from 50 to $100 \mu \mathrm{g} / \mathrm{g}$ in fresh grape skin and from 0.1 to $14 \mathrm{mg} / \mathrm{l}$ in red wine $(44,45)$. It is synthesized in plants in response to injury or fungal attack. Different studies have found that resveratrol has antioxidant and anti-inflammatory effects, ameliorating inflammation through counteracting with TNF- $\alpha-$ induced effects and declining mRNA expression and secreting different adipokines such as plasminogen activator inhibitor-1 (PAI-1), IL-1 $\beta$, IL-6, IL-8, and MCP-1. Resveratrol and curcumin increase pancreatic $\beta$-cell function by inhibiting phosphodiesterase activity. They protect against $\beta$-cell dysfunction. In T2DM, cAMP plays an important role in glucose and incretinstimulated insulin secretion as well as overall pancreatic $\beta$-cell health. A potential therapeutic target in managing T2DM is to regulate the activity of phosphodiesterases (PDEs), which degrade cAMP. Both resveratrol and curcumin have been reported to act as PDE inhibitors in various cell types, but it remains unknown whether they do so in pancreatic $\beta$-cells. Treating $\beta$-cell lines and human islets with these polyphenols has led to an increase in intracellular cyclic adenosine monophosphate (cAMP) levels. Resveratrol and curcumin increase pancreatic $\beta$-cell function through inhibiting phosphodiesterase activity and promote $\beta$-cell function across species by acting as direct PDE inhibitors in $\beta$-cells and islets. Treatment of mouse and human $\beta$-cells with resveratrol and curcumin resulted in a substantial reduction of PDE expression, particularly PDE3B, PDE8A, and PDE10A, which are known to be important in insulin signaling (46). Also, resveratrol and curcumin treatment showed a profound ability to directly inhibit PDE activity in $\beta$-cells of pancreas. As a result of PDE inhibition, resveratrol and curcumin treatment prevented the degradation of cAMP, leading to an increase in its intracellular levels. Subsequently, this allowed for activation of cAMP-dependent signaling pathways, augmenting insulin secretion and $\beta$-cell function (46).

Resveratrol effects on weight reduction induced by several mechanisms include increasing apoptosis, fat mobilization, fatty acids oxidation, lipolysis, and decrease in lipogenesis and adipogenesis. Table 2 displays an overview of recent clinical trials testing resveratrol with respect to diabetic and inflammatory markers.

\section{Cinnamon}

with Type 2 diabetes through improving the ability to respond to insulin. A total of 8 meta-analysis clinical studies demonstrated that cinnamon or cinnamon extracts decrease fasting blood glucose levels (51). Cinnamon slows the rate of stomach emptying after eating. In the study of Hlebowicz et al., participants ate a cup of rice pudding with and without a teaspoon of cinnamon. Adding cinnamon decreased the rate of stomach emptying from $37 \%$ to $34.5 \%$ and significantly decreased the rise in blood sugar levels at 0 and 120 minutes compared to ingestion of the reference meal. Even less than half a teaspoon a day reduced blood sugar levels of patients with type 2 diabetes (52).

\section{Capsaicin}

Capsaicin is an active component in chili peppers and is usually consumed as a spice, but it is also used for neurological disorders, such as diabetic neuropathy and tropical therapy of cutaneous allergy. Capsaicin specifically binds to ion channel, which is activated by several physical and chemical stimuli and causes pungent sensation in mammals (53). Moreover, studies illustrated that it can activate AMPK and suppress adipocyte differentiation in mouse adipocytes (54). In murine macrophages, capsaicin's anti-inflammatory action was shown by repressing the expression of proinflammatory gene inducible nitric oxide synthase (iNOS). It also represses cyclooxygenase 2 (COX2) activity, inhibits prostaglandin E2 (PGE2) production, and inactivates NF- $\kappa$ B by inhibiting $(\mathrm{I} \kappa \mathrm{B} \alpha)$ degradation (55). Also, it binds specifically to PPAR $\gamma$ and suppresses the production of TNF- $\alpha$. Hence, capsaicin's anti-inflammatory effect is assumed to be mediated through activation of PPAR $\gamma$ and NF- $\mathrm{KB}$ $(56,57)$. Screening different plant extracts also determined its potential to activate PPAR $\alpha$ (58). In mouse adipocytes, capsaicin inhibits adipogenesis and decreas-

Table 2. Overview of recent clinical trials testing resveratrol with respect to diabetic and inflammatory markers

\begin{tabular}{|c|c|c|c|}
\hline Treatment group & Dose; duration & Ref. & Effect of resveratrol \\
\hline 11 healthy, obese males & $150 \mathrm{mg}$ resveratrol $/ \mathrm{d} ; 30 \mathrm{~d}$ & $(47)$ & $\begin{array}{l}\text { Decrease in metabolic rate, mimicking the effect of calorie } \\
\text { restriction }\end{array}$ \\
\hline 10 T2DM patients & $10 \mathrm{mg}$ resveratrol $/ \mathrm{d} ; 4 \mathrm{w}$ & $(48)$ & Reduction of insulin resistance \\
\hline $\begin{array}{l}10 / 10 / 10 / 10 \\
\text { healthy participants }\end{array}$ & $0.5 / 1 / 1.5 / 2 \mathrm{~g}$ resveratrol $/ \mathrm{d} ; 29 \mathrm{~d}$ & $(49)$ & $\begin{array}{l}\text { Reduction of IGF-1 and IGFBP-3 in plasma and gastrointesti- } \\
\text { nal symptoms on } 2 \text { highest dose levels }\end{array}$ \\
\hline 10 healthy participants & $200 \mathrm{mg}$ PCE (40 mg resveratrol $) / \mathrm{d} ; 6 \mathrm{w}$ & $(50)$ & $\begin{array}{l}\text { Suppression of oxidative and inflammatory stress markers } \\
\text { including the reduction in ROS generation, the expression of } \\
\text { p } 47 \text { phox, intranuclear NF- } \kappa \text { B binding, the expression of jun- } \\
\text { N-terminal kinase- } 1 \text {, inhibition of } \kappa B-k i n a s e-\beta \text {, phosphotyro- } \\
\text { sine phosphatase- } 1 \mathrm{~B} \text {, and suppression of cytokine signaling- } 3 \\
\text { in mononuclear cells and plasma TNF- } \alpha \text {, IL- } 6 \text {, and C-reactive } \\
\text { protein }\end{array}$ \\
\hline
\end{tabular}

T2DM: Type 2 diabetes mellitus; d: days; w: weeks; IGF-1: insulin-like growth factor 1; IGFBP-3: insulin-like growth factor binding protein 3; ROS: reactive oxygen

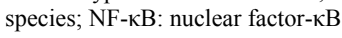




\begin{tabular}{|c|c|c|c|}
\hline $\begin{array}{l}\text { Treatment } \\
\text { group }\end{array}$ & Dose; duration & Ref. & Effect of capsaicin \\
\hline 18 healthymales & 9 mg capsinoids; once (FDG-PET) & (69) & $\begin{array}{l}\text { Activation of brown adipose tissue, enhancement in energy } \\
\text { expenditure }\end{array}$ \\
\hline $\begin{array}{l}25 \text { healthy } \\
\text { participants }\end{array}$ & $\begin{array}{l}1 \mathrm{~g} \text { red pepper }(1995 \mu \mathrm{g} \text { capsaicin, } 247 \mu \mathrm{g} \text { nordihy- } \\
\text { drocapsaicin, and } \\
1350 \mu \mathrm{g} \text { dihydrocapsaicin); once }\end{array}$ & $(70)$ & Enhancement in energy expenditure and body temperature \\
\hline $\begin{array}{l}12 \text { healthy } \\
\text { participants }\end{array}$ & $26.6 \mathrm{mg}$ capsaicin (5 g capsicum); once (OGTT) & $(68)$ & Decrease in plasma glucose levels; increase in insulin levels \\
\hline $\begin{array}{l}27 \text { healthy } \\
\text { participants }\end{array}$ & $510 \mathrm{mg}$ cayenne $/ 510 \mathrm{mg}$ cayenne t.w. green tea; once & $(71)$ & $\begin{array}{l}\text { Decrease of energy intake and hunger and enhancement in } \\
\text { satiety (in combination with green tea) }\end{array}$ \\
\hline $\begin{array}{l}36 \text { healthy } \\
\text { participants }\end{array}$ & $\begin{array}{l}33 \mathrm{mg} \text { capsaicin ( } 30 \mathrm{~g} \text { chili blend }[55 \% \text { cayenne } \\
\text { chili] }) / \mathrm{d} ; 4 \mathrm{w}\end{array}$ & $(72)$ & $\begin{array}{l}\text { No change of metabolic parameters (plasma glucose, serum } \\
\text { lipids, lipoproteins, insulin, metabolic rate) }\end{array}$ \\
\hline $\begin{array}{l}14 \text { healthy } \\
\text { participants }\end{array}$ & $400 \mu \mathrm{g}$ capsaicin; once (glucose loading test) & $(73)$ & Slight increase in glucose absorption and glucagon release \\
\hline $\begin{array}{l}27 \text { healthy } \\
\text { participants }\end{array}$ & $\begin{array}{l}33 \mathrm{mg} \text { capsaicin ( } 30 \mathrm{~g} \text { chili blend }[55 \% \text { cayenne } \\
\text { chili])/d; } 4 \mathrm{w}\end{array}$ & (74) & $\begin{array}{l}\text { Inhibition of oxidation of serum lipoproteins; no difference } \\
\text { in the serum lipid, lipoproteins, total anti-oxidation status }\end{array}$ \\
\hline $\begin{array}{l}36 \text { healthy } \\
\text { participants }\end{array}$ & $\begin{array}{l}33 \mathrm{mg} \text { capsaicin ( } 30 \mathrm{~g} \text { chili blend [ } 55 \% \text { cayenne } \\
\text { chili])/d; } 4 \mathrm{w}\end{array}$ & $(75)$ & Attenuation of postprandial hyperinsulinemia \\
\hline
\end{tabular}

es the amount of intracellular triglycerides. Thermogenesis is enhanced by capsaicin (59). Through stimulating lipolysis and thermogenesis, capsaicin increases the energy expenditure in adipose tissue (60). More recently, it has been shown that capsaicin induces concentrationdependent $(0.1-10 \mu \mathrm{M})$ upregulation of the mitochondrial UCP-2 (uncoupling protein 2), a mitochondrial protein transporter that separates oxidative phosphorylation from ATP synthesis with energy dissipated as heat and other genes involved in lipid catabolism in white adipocytes (61). Another study on adipocytes revealed that activation of VR1 by capsaicin concentrations, starting from $10 \mathrm{nM}$, promotes a calcium influx and prevents adipogenesis and obesity, which has also been confirmed in vivo (62). This property of capsaicin likely explains the activation of further downstream targets. In earlier studies on rats, it has been shown that capsaicin stimulates lipid mobilization from adipose tissue and decreases the perirenal adipose tissue weight and serum triglyceride concentration if added to $0.014 \%$ of the diet (63). This was also associated with an increased energy metabolism and an enhanced respiratory quotient (64). More investigations in mice suggest that capsaicin suppresses obesity-induced inflammation by modulating adipokine release. Also, it suppresses the expression and secretion of IL-6 and MCP-1 from obese adipose tissues, but increases adiponectin gene expression. Intraperitoneal administration of capsaicin $(2 \mathrm{mg} / \mathrm{kg} \mathrm{bw})$ suppresses macrophage activation and decreases the release of proinflammatory mediators and stops their migration $(57,65)$. Capsaicin also counteracts the proinflammatory effects of saturated fatty acids through reduction in JNK activity, thus it may be regarded as a beneficial phytochemical for attenuating obesity-induced inflammation and obesity-related pathologies. In some studies, an increased fat oxidation (66) and a lowered fat intake (67) were observed in overweight participants treated with capsaicin. More recent studies investigating the effect of dietary capsaicin showed an effect on glucose and insulin. Capsaicinalso seems to be involved in the regulation of energy expenditure and activation of brown adipose tissue in humans (68). Table 3 demonstrates recent clinical trials testing capsaicin with respect to diabetic and inflammatory markers.

\section{Catechins and Procyanidins}

Catechins are flavanols that contain catechin (C), epicatechin (EC), gallocatechin (GC), epigallocatechin (EGC), and their gallates. Cocoa is very rich in catechins and flavanol-based oligomers known as procyanidins (76). Procyanidins positively affect inflammatory diseases, such obesity and Type 2 diabetes. They can modulate inflammation through decreasing the expression of IL- 6 and MCP-1 and increasing the production of anti-inflammatory adipokine and adiponectin (77). Table 4 displays recent clinical trials testing catechin with respect to diabetic and inflammatory markers.

\section{Berberine}

Berberin is a bitter compound found in the roots of several plants including goldenseal, barberry, and oregon grape. Studies have found that berberin can lower blood glucose. Chinese researchers compared berberine with metformin in a pilot study on 36 participants. They found that berberine ( $0.5 \mathrm{~g} 3$ times a day) decreased blood sugar level just as well as metformin in 3 months. Berberin also significantly reducd fasting blood sugar and after meal blood sugar of patients (99). In the same study, researchers gave berberine $(0.5 \mathrm{~g} 3$ times a day) to 48 patients with diabetes for 3 months. They found that berberine dicreased fasting and post meal blood glucose levels after 1 week. They also found that the patients' insulin resistance decreased to $45 \%$ (99). A meta-analysis on 14 studies involving 1068 participants has revealed that berberine effects are similar to those of metformin, glipizide, and rosiglitazone. These drugs are the most important diabetes drugs on the market (100). Most importantly, berberine has no serious side effects. Table 5 demonstrates recent clinical trials testing berberine with respect to diabetic and inflammatory markers. 
Table 4. Overview of recent clinical trials testing catechin with respect to diabetic and inflammatory markers

\begin{tabular}{|c|c|}
\hline Treatment group & Dose; duration \\
\hline 15 ow-ob participants & $\begin{array}{l}650 \mathrm{ml} \text { green tea }(534 \mathrm{mg} \text { catechins t.w. } 11.7 \mathrm{~g} \\
\text { inulin)/d; } 6 \mathrm{w}\end{array}$ \\
\hline 64 ow-ob males & $\begin{array}{l}1060 \mathrm{mg} \text { GTE ( } 424-753 \mathrm{mg} \text { EGCG t.w. 170-286 } \\
\mathrm{mg} \text { EGC, } 85-784 \mathrm{mgEC}) / \mathrm{d} ; 6 \mathrm{w}\end{array}$ \\
\hline 80 T2DM patients & $1500 \mathrm{mg}$ GTE (856 mg EGCG)/d; $16 \mathrm{w}$ \\
\hline 19 healthy males & $491 \mathrm{mg}$ catechins t.w. oolong tea/d; $5 \mathrm{~d}$ \\
\hline 8 healthy participants & $405 \mathrm{mg}$ EGCG/d; $2 \mathrm{~d}$ \\
\hline $\begin{array}{l}22 \text { healthy pmp fe- } \\
\text { males }\end{array}$ & $\begin{array}{l}\text { One group consumed a catechin-rich green tea } \\
\text { (catechins } 615 \mathrm{mg} / 350 \mathrm{ml} \text { ) and another consumed } \\
\text { a placebo (catechins } 92 \mathrm{mg} / 350 \mathrm{ml} \text { ) beverage per d } \\
\text { for } 4 \text { weeks }\end{array}$ \\
\hline $\begin{array}{l}13 / 10 \text { ob patients } \\
\text { with MetS }\end{array}$ & $\begin{array}{l}4 \text { cups green tea }(440 \mathrm{mg} \text { EGCG t.w } 220 \mathrm{mg} \text { EGC, } \\
180 \mathrm{mg} \text { ECG, and } 88 \mathrm{mg} \text { EC) } / 2 \text { capsules GTE ( } 460 \\
\mathrm{mg} \text { EGCG t.w. } 240 \mathrm{mg} \text { EGC, } 120 \mathrm{ECG} \text {, } \\
\text { and } 50 \mathrm{mg} \text { EC) } / \mathrm{d} ; 8 \mathrm{w}\end{array}$ \\
\hline $\begin{array}{l}47 / 49 / 43 \text { ow partici- } \\
\text { pants }\end{array}$ & $\begin{array}{l}458 \mathrm{mg} \text { green tea catechins t.w. } 104 \mathrm{mg} \text { caf- } \\
\text { feine } / 468 \mathrm{mg} \text { catechin } \\
\text { t.w. } 126 \mathrm{mg} \text { caffeine } / 886 \mathrm{mg} \text { catechins t.w. } 198 \mathrm{mg} \\
\text { caffeine } / \mathrm{d} ; 90 \mathrm{~d}\end{array}$ \\
\hline 10 ow-ob males & $300 / 600 \mathrm{mg}$ EGCG/d; $3 \mathrm{~d}$ \\
\hline $\begin{array}{l}10 \text { healthy } \\
\text { smokers }\end{array}$ & $\begin{array}{l}580 \mathrm{mg} \text { green tea catechins }(102 \mathrm{mg} \text { EGCG, } 77 \mathrm{mg} \\
\mathrm{EGC}, 30 \mathrm{mg} \text { ECG, } \\
129 \mathrm{mg} \text { GCG }, 138 \mathrm{GC}, 38 \mathrm{mg} \mathrm{C}) / \mathrm{d} ; 2 \mathrm{w}\end{array}$ \\
\hline $\begin{array}{l}100 \text { tuberculosis } \\
\text { patients }\end{array}$ & $500 \mu \mathrm{g}$ catechin extract $3 \times /$ week; $4 \mathrm{~m}$ \\
\hline 46 ow-ob males & 800 mg EGCG;/d; 8 w \\
\hline 23 T2DM patients & $583 \mathrm{mg}$ green tea catechins $/ \mathrm{d} ; 12 \mathrm{w}$ \\
\hline 21 ob children & $576 \mathrm{mg}$ green tea catechins $/ \mathrm{d} ; 24 \mathrm{w}$ \\
\hline $\begin{array}{l}12 / 11 \text { healthy } \\
\text { males }\end{array}$ & 3 capsules GTE (366 mg EGCG)/d; $1 \mathrm{~d}$ \\
\hline $\begin{array}{l}60 \text { with elevated } \\
\text { blood glucose }\end{array}$ & $\begin{array}{l}\text { GTE powder ( } 456 \mathrm{mg} \text { catechins t.w. } 102 \mathrm{mg} \text { caf- } \\
\text { feine) } / \mathrm{d} ; 2 \mathrm{~m}\end{array}$ \\
\hline 29 healthy adults & $500 \mathrm{mg}$ green te \\
\hline $\begin{array}{l}\text { 16/17 T2DM } \\
\text { patients }\end{array}$ & $\begin{array}{l}150 / 300 \mathrm{mg} \text { green tea catechins t.w. } 75 \mathrm{mg} \text { of } \\
\text { black tea theaflavins } / \mathrm{d} ; 3 \mathrm{~m}\end{array}$ \\
\hline $\begin{array}{l}19 \text { ow-ob, pmp } \\
\text { women }\end{array}$ & 300 mg EGCG/d; 12 w \\
\hline 6 ow males & $300 \mathrm{mg}$ EGCG/d; $2 \mathrm{~d}$ \\
\hline
\end{tabular}

(78) Reduction of body weight, fat mass, body mass index, and blood pressure

(79) Reduction of body weight; no effect on blood pressure or biomarkers of metabolic function

(80) No significant effect in fasting glucose, $\mathrm{HbA1C}$, hormone peptides, and plasma lipoproteins

(81) No effect on glucose metabolism

(82) No influence on resting metabolism and the thermic effect of food

(83) Decrease in postprandial glucose concentrations, Inhibition of the increase in the serum concentrations of the derivatives of reactive oxygen metabolites

(84, Reduction of body weight, BMI, lipid peroxidation,

85) and plasma serum amyloid alpha; no effect on inflammatory markers or features of MetS

(86) Reduction of intra-abdominal fat, waist circumference and body weight with highest dose, total body fat mass with low and medium doses; no effect on plasma HDL cholesterol and LDL cholesterol, triglycerides, and glucose levels

(87) No effect on energy expenditure; enhancement of postprandial fat oxidation only by low EGCG dose

(88) Enhancement of NO production, reduction of oxidative stress; decrease of MCP-1 level

(89) Reduction of oxidative stress with significantly decreased lipid oxidation and increased NO levels

(90) No effect on insulin sensitivity, insulin secretion, or glucose tolerance; reduction of diastolic blood pressure

(91) Decrease in waist circumference; increase in adiponectin and insulin levels; no effect on glucose and $\mathrm{HbAlc}$

(92) Decrease in waist circumference, systolic blood pressure, and LDL cholesterol

(93) Increase in fat oxidation during exercise; improvement in insulin sensitivity and glucose tolerance

(94) Reduction in $\mathrm{HbAlc}$ and diastolic blood pressure; no effect on weight, body fat, systolic blood pressure, HOMA index, serum lipid, and glucose level

(95) Reduction in oxidized LDL cholesterol

(96) No effect on HbAlc

(97) Reduction of heart rate and plasma glucose concentration in participants with impaired glucose tolerance (98) Decrease in respiratory quotient; no effect on energy expenditure

Ow : overweight; ob: obese; pmp: postmenopausal; T2DM: Type 2 diabetes mellitus; MetS: metabolic syndrome; d: days; w: weeks; m: months; GTE: green tea extract; EGCG: epigallocatechin gallate; EGC: epigallocatechin; ECG: epicatechin gallate; EC: epicatechin; C: catechin; GC: gallocatechin; GCG:gallocatechin gallate; GA: gallic acid; t.w.: together with; HbA1c: hemoglobin A1c; BMI: body mass index; NO: nitric oxide; MCP-1: monocyte chemoattractant protein-1; HOMA: homeostatic model assessment

\section{Genistein}

The isoflavone genistein is a naturally occurring phytoestrogen, which is particularly highly concentrated in soy and soy-derived products; its possible suitability as a pharmacological agent has been studied, as it has been illustrated that people in Asia consuming large amounts of genistein-rich soy products are seldom affected by prostate or breast cancer $(104,105)$ and Type 2 diabetes (106). In hypoxic conditions, genistein has been shown to suppress the HIF1 $\alpha$ expression, accumulation, and activation of ERK $(107,108)$. Also, genistein seems to provide a protective effect on myocardial and endotheli- al cells, as it activates the exocytosis of the cardioprotective neuropeptide calcitonin gene-related peptide. This is due to vanillin receptor 1(VR1)-mediated action, of which genistein is supposed to be a direct activator (109), apart from capsaicin and gingerol. In adipocytes, genistein acts as an anti-inflammatory substance, downregulates leptin production in the presence of 50 $\mu \mathrm{M}(110)$, induces apoptosis at $100 \mu \mathrm{M}$ (111), and also counteracts the antilipolytic action of insulin if used at concentrations higher than $12.5 \mu \mathrm{M}(112)$. This is probably due to PPAR $\gamma$, to which genistein is a direct ligand and activator (113). However, the effect of genistein on differentiation of adipocytes has been illustrated with 


\begin{tabular}{|c|c|c|c|}
\hline Treatment group & Dose; duration & Ref. & Effect of berberine \\
\hline 36 T2DM patients & $1.5 \mathrm{~g} / \mathrm{d}$ berberine for 3 months & $(99)$ & $\begin{array}{l}\text { Decrease in HbA1c, fasting blood glucose, postprandi- } \\
\text { al blood glucose, and TG }\end{array}$ \\
\hline $31 \mathrm{~T} 2 \mathrm{DM}$ patients & 3 extract of barberries vulgaris $\mathrm{g} / \mathrm{d}$ for 3 months & $(101)$ & $\begin{array}{l}\text { Decrease in TG,TC, LDL, apo B, Glc, insulin and } \\
\text { increase in total antioxidant capacity }\end{array}$ \\
\hline 69 T2DM patients & $\begin{array}{l}1000 \mathrm{mg} \text { berberine, } 1000 \mathrm{mg} \text { berberine and } 210 \\
\mathrm{mg} \text { silymarin for } 4 \mathrm{~m}\end{array}$ & $(102)$ & $\begin{array}{l}\text { Decrease in Glc, TC, TG, LDL, AST, ALT, } \\
\mathrm{Hb} \text { Alc }\end{array}$ \\
\hline 30 T2DM patients & $2 \mathrm{mg}$ barberries fruit extract $/ \mathrm{d}$ for $2 \mathrm{~m}$ & $(103)$ & Decrease in Glc and $\mathrm{Hb} \mathrm{A} 1 \mathrm{c}$ \\
\hline \multicolumn{4}{|c|}{$\begin{array}{l}\text { T2DM type } 2 \text { diabetes mellitus; g: gram; d: days; m: months; TG: triglyceride; TC: total cholesterol; Glc: glucose; AST: Aspartate Aminotransferase; ALT: alanine } \\
\text { aminotransferase; Hb A1c: hemoglobin A1c }\end{array}$} \\
\hline \multicolumn{4}{|c|}{ Table 6. Overview of recent clinical trials testing genistein with respect to diabetic and inflammatory markers } \\
\hline Treatment group & Dose; duration & Ref. & Effect of genistein \\
\hline $\begin{array}{l}23 \text { patients with prostate } \\
\text { cancer }\end{array}$ & $30 \mathrm{mg}$ genistein/d; $3-6 \mathrm{w}$ & $(123)$ & Reduction of blood cholesterol \\
\hline 43 healthy, ob, pmp females & $\begin{array}{l}60.8 \mathrm{mg} \text { genistein (t.w. } 16 \mathrm{mg} \text { daidzein }+3.2 \mathrm{mg} \\
\text { glycitein) } / \mathrm{d} ; 6 \mathrm{~m}\end{array}$ & (124) & Enhancement of adiponectin serum levels \\
\hline $\begin{array}{l}71 \text { pmp osteopenic } \\
\text { females }\end{array}$ & $54 \mathrm{mg}$ genistein/d; 24/36 m & $(125)$ & $\begin{array}{l}\text { Reduction of fasting glucose and insulin, HOMA- } \\
\text { IR, fibrinogen and homocysteine after } 24 / 36 \\
\text { months of treatment }\end{array}$ \\
\hline $\begin{array}{l}30 \text { pmp normo- and hyperin- } \\
\text { sulinemic females }\end{array}$ & $54 \mathrm{mg}$ genistein/d; $24 \mathrm{w}$ & $(126)$ & $\begin{array}{l}\text { Reduction of fasting glucose in normoinsulinemic } \\
\text { patients; reduction in fasting insulin, fasting C- } \\
\text { peptide; improvement of HDL levels }\end{array}$ \\
\hline 32 healthy, pmp females & $\begin{array}{l}64 \mathrm{mg} \text { genistein (t.w. } 63 \mathrm{mg} \text { daidzein and } 34 \\
\text { mg glycitein)/d; } 12 \mathrm{w}\end{array}$ & $(127)$ & $\begin{array}{l}\text { Enhancement in serum adiponectin levels; no } \\
\text { effect on metabolic parameters }\end{array}$ \\
\hline $25 \mathrm{pmp}$ females & $2 \mathrm{mg}$ genistein (t.w. $4.8 \mathrm{mg}$ daidzein) $/ \mathrm{d} ; 6 \mathrm{~m}$ & $(128)$ & No significant effect \\
\hline
\end{tabular}

inconsistent results; this is in part due to contradictory actions of genistein with respect to applied concentrations $(110,111,113-119)$. In a study, streptozotocindiabetic rats that received a daily intraperitoneal injection of $1 \mathrm{mg} / \mathrm{kg}$ bw showed a hypoglycemic effect (120). In a study on mice, 2 and $4 \mathrm{~g}$ genistein $/ \mathrm{kg}$ diet significantly decreased fat pads, cholesterol, and lipid levels. Moreover, it inhibited mRNA expression of PPAR $\gamma$, leptin, and TNF $\alpha$ and also increased mRNA expression in case of PPAR $\alpha$, AMPK, and adiponectin in adipose tissue (121). Furthermore, it enhanced the expression of genes involved in fatty acid oxidation, and at the same time, activated expression of UCP2, which mediates proton leakage by uncoupling ATP synthesis. This lowered metabolic efficiency may also account for the reduced fat accumulation and weight gain in animals receiving a daily genistein dose of about 200,400 , or $800 \mathrm{mg} / \mathrm{kg}$ of the body weight (117). Similar to resveratrol, genistein administration decreased the ATP level in adipocytes (122). Recent clinical trials on genistein in males showed an increase in adiponectin levels and a decrease in cholesterol and insulin levels, with doses that can easily be obtained by a soy rich diet. Table 6 displays recent clinical trials testing genistein with respect to diabetic and inflammatory markers.

\section{Combined effects of natural products}

Table 7. Overview of recent clinical trials testing quercetin with respect to diabetic and inflammatory markers

\begin{tabular}{|c|c|c|c|}
\hline Treatment group & Dose; duration & Ref. & Effect of quercetin \\
\hline 20 athletes & $\begin{array}{l}1000 \mathrm{mg} \text { quercetin t.w. } 1000 \mathrm{mg} \text { Vitamin } \mathrm{C} \text {, } \\
40 \mathrm{mg} \text { niacinamide } 120 \text { etc.; once }\end{array}$ & $(133)$ & No postexercise inflammation or immune changes \\
\hline $\begin{array}{l}\text { 334/333 non-smoking, } \\
\text { un-treated sarcoidosis } \\
\text { patients }\end{array}$ & $\begin{array}{l}500 / 1000 \mathrm{mg} \text { quercetin (t.w. } 125 / 250 \mathrm{mg} \\
\text { Vit. C and } 5 / 10 \mathrm{mg} \text { niacin)/d; } 2 \mathrm{w}\end{array}$ & $(134)$ & Little reduction in HDL cholesterol level and IL-6 \\
\hline $\begin{array}{l}12 \text { sarcoidosis } \\
\text { patients }\end{array}$ & $2000 \mathrm{mg}$ quercetin within $24 \mathrm{~h}$ & $(135)$ & $\begin{array}{l}\text { Increase in TAC, decrease in serum MDA, TNFa/IL- } 10 \\
\text { and IL-8/IL-10 ratio, no effect on serum glutathione }\end{array}$ \\
\hline 6 healthy females & 150 mg quercetin; once & $(136)$ & $\begin{array}{l}\text { No changes for respiratory quotient, resting energy } \\
\text { expenditure, pulse or blood pressure }\end{array}$ \\
\hline $\begin{array}{l}38 / 40 \text { healthy } \\
\text { females }\end{array}$ & $500 / 1000 \mathrm{mg}$ quercetin/d; $12 \mathrm{w}$ & $(137)$ & $\begin{array}{l}\text { No influence on innate immune function or inflammato- } \\
\text { ry markers IL- } 6 \text { and TNF- } \alpha \text { or body fat }\end{array}$ \\
\hline $\begin{array}{l}93 \text { ow patients } \\
\text { with MetS }\end{array}$ & $150 \mathrm{mg}$ quercetin/d; $6 \mathrm{w}$ & $(138)$ & $\begin{array}{l}\text { Reduction of blood pressure, plasma oxidized LDL, and } \\
\text { TNF- } \alpha \text { (dependent on apolipoprotein E genotype) }\end{array}$ \\
\hline $\begin{array}{l}20 \text { rheumatoid arthritis } \\
\text { patients }\end{array}$ & $\begin{array}{l}498 \mathrm{mg} \text { quercetin (t.w. } 399 \mathrm{mg} \text { Vit. C)/d; } 4 \\
\text { w }\end{array}$ & $(139)$ & No significant change of inflammation markers in blood \\
\hline 93 ow with MetS & $150 \mathrm{mg}$ quercetin/d; $6 \mathrm{w}$ & $(140)$ & $\begin{array}{l}\text { Reduction of blood pressure, serum HDL-cholesterol, } \\
\text { and oxidized LDL plasma concentration; no effect on } \\
\text { TNF- } \alpha\end{array}$ \\
\hline 35 healthy participants & $50-150 \mathrm{mg}$ quercetin/d; $2 \mathrm{w}$ & $(141)$ & $\begin{array}{l}\text { No effect on TNF- } \alpha \text { and oxidized LDL- concentration; } \\
\text { no significant change of body composition, resting } \\
\text { energy expenditure serum lipids, and lipoproteins }\end{array}$ \\
\hline 47 T2DM patients & $\begin{array}{l}\text { Received oral quercetin }(250 \mathrm{mg} / \mathrm{d}) \text { or iden- } \\
\text { tical placebo (cellulose) capsules for } 8 \mathrm{w}\end{array}$ & $(142)$ & $\begin{array}{l}\text { Improvement of TAC and reduction of serum concen- } \\
\text { tration of atherogenic oxidized LDL }\end{array}$ \\
\hline
\end{tabular}

Ow: overweight; MetS: metabolic syndrome; T2DM: Type 2 diabetes mellitus; d: days; w: weeks; t.w.: together with; IL: interleukin; TNF $\alpha$ : tumor necrosis factor $\alpha$; TAC: total antioxidant capacity; MDA: Malondialdehyde 
Some studies propose that the anti-inflammatory and antidiabetic impacts of these natural products could be achieved even if fewer doses are used in combination. These combinations synergistically enhance their antiinflammatory activity and the therapeutic effect on inflamed adipose tissue. Resveratrol and quercetin in combination activated caspase- 3 in human pancreatic carcinoma cells (129), inhibited lipid accumulation, declined the expression of PPAR $\gamma$, and enhanced apoptosis in 3T3-L1 mouse adipocytes. The effect was more than the expected additive response (130). Another study demonstrated that genistein and resveratrol in combination have a more potent impact on inhibiting adipogenesis and stimulating apoptosis (at dose $100 \mu \mathrm{mol} / \mathrm{L}$ genistein $+100 \mu \mathrm{mol} / \mathrm{L}$ resveratrol) and promoting lipolysis (at dose $25 \mu \mathrm{mol} / \mathrm{L}$ genistein $+25 \mu \mathrm{mol} / \mathrm{L}$ resveratrol) in 3T3-L1 mouse preadipocytes and mature adipocytes than each of these compounds alone (131). It was also reported that the combined treatment of primary human adipocytes with low concentrations of genistein, quercetin, and resveratrol suppressed lipid aggregation in maturing adipocytes, declined cell viability, and stimulated apoptosis, whereas the treatment of the compounds alone had no apoptosis inducing impact (132). Hence, possible toxic impacts could be prevented by decreasing the dosage of each single natural compound. In general, with respect to the data from clinical studies, a combination of several phytochemicals seems to exceed the effect of single administration. Thus, in patients with T2DM or other inflammatory diseases, a more comprehensive knowledge on reasonable combinations of the mentioned phytochemicals can be useful. Interestingly, many natural products contain a well-established combination of several phytochemicals like green tea, grapes, or other fruits, and vegetables. Table 7 shows recent clinical trials testing quercetin with respect to diabetic and inflammatory markers.

\section{Ginger (Zingiber Officinale Roscoe)}

The main pharmacological actions of ginger include immunomodulatory, antitumorogenesis, antiinflammatory, antiapoptosis, and antiemetic. Ginger has different components such as gingerols, shogaols, paradols, gingerdiols, etc.

Ginger is the underground stem of the plant Zingiber Officinale and most likely originates from southern china. Gingerol has been identified as a major bioactive component. Moreover, 6-gingerol, with a concentration of about $1.3-1.9 \mathrm{mg} / \mathrm{g}$ ginger, is the most abundant component in the ginger extract, which has been known to have a strong anti-inflammatory activity $(143,144)$. Gingerols also possess immunosuppressive (145) and antitumor-promoting properties. They inhibit the expression of COX-2 through inhibiting p38 MAPK and $\mathrm{NF}-\kappa \mathrm{B}$ activation (146) and decrease TNF- $\alpha$ expression, inflammation, and tumor promotion after application to the skin of mice $(5,147)$. Also, it has recently been reported that 6-gingerol can upregulate HIF-1 $\alpha$ during mouse embryogenesis and prevent developmental disor- ders in the context of hypoxia (148). However, PPAR $\gamma$ is not affected by gingerol, which contradicts other phytochemicals (149). Treatment of mouse adipocytes with gingerol increased differentiation and enhanced insulin sensitive and glucose uptake; hence, it is expected to improve the diabetic state as well (150). Moreover, 6gingerol at concentrations of 10 and $25 \mu \mathrm{M}$ was shown to have additional effect on the regulation of adipocyte function through inhibiting TNF- $\alpha$-mediated decrease of adiponectin expression in mouse adipocytes via inhibiting JNK phosphorylation (149). Because of its structural homology to spice-derived compound capsaicin, gingerol is a further VR1 agonist (151), which might play a role in suppressing inflammatory responses of adipose tissue in obesity (152). In a study, animals that were fed a high- fat diet showed a significantly increased serum insulin concentration and better glucose tolerance if their diet was enriched with $2 \%$ ginger (153). In a similar study, the daily intraperitoneally administration of raw ginger extract $(500 \mathrm{mg} / \mathrm{kg}$ bw) significantly decreased serum glucose, triacylglycerol, and cholesterol levels and reversed diabetic proteinuria (154). A recent in vivo study using high-fat fed mice showed that after adding $0.05 \%$ 6-gingerol supplementation to the mice diet, their body weight gain and adiposity in association with a modified cholesterol metabolism and fatty acid oxidation significantly decreased (155). However, to obtain an equivalent content of 6-gingerol, consumption of about $2.5 \mathrm{~g}$ /day of fresh ginger rhizome per $\mathrm{kg}$ bw (a $30 \mathrm{~g}$ mouse consuming $3 \mathrm{~g}$ /day) is necessary. Also, the administration of a ginger extract to diabetic rats $(200$ $\mathrm{mg} / \mathrm{kg} \mathrm{bw}$ ) reduced their blood glucose levels and affected intra and extramitochondrial enzyme activities (156).

These animal studies show that ginger possesses hypocholesterolemic, hypolipidemic, and hypoglycaemic potential, and thus may be of value in humans. There are only few recent clinical trials focusing on the applicability of gingerol for the treatment of diabetes or related purposes in humans. Recent studies have found that consuming gingerol with the doses between $100 \mathrm{mg}$ and $3 \mathrm{~g}$ can lower eicosanoid and lipid levels (157). In Arablou et al. study, 70 diabetic patients were enrolled and consumed $1600 \mathrm{mg}$ ginger versus $1600 \mathrm{mg}$ wheat flour for 12 weeks; and they found that ginger decreased Creactive protein and prostaglandin E2 (significantly), fasting plasma glucose, hemoglobin $\mathrm{A} 1 \mathrm{C}$, insulin, and HOMA index compared to placebo group. However, there were no significant differences in tumor necrosis factor $\alpha$ between the 2 groups (158). In another study, Mahluji et al. found that taking $2 \mathrm{~g}$ of ginger per day for 2 months has no effect on FPG and $\mathrm{HbA}_{1 \mathrm{C}}$, but can decrease serum insulin and HOMA. This difference is attributable to longer duration of study (159). Bordia et al. observed no significant changes in blood sugar levels in healthy individuals and patients with CAD and Type 2 diabetes with or without CAD after receiving $3 \mathrm{~g}$ ginger for 3 months (160). Thus, ginger can probably reduce Creactive protein, prostaglandin $\mathrm{E} 2$, blood glucose, insulin levels, and improve insulin sensitivity patients with 
Table 8. Overview of recent clinical trials testing ginger with respect to diabetic and inflammatory markers

\begin{tabular}{|c|c|c|c|}
\hline Treatment group & Dose; duration & Ref. & Effect of ginger \\
\hline 16 healthy participants & $2 \mathrm{~g}$ ginger extract $/ \mathrm{d} ; 28 \mathrm{~d}$ & $(161)$ & Reduction in PGE2 and other eicosanoids \\
\hline $\begin{array}{l}45 \text { patients with } \\
\text { hyperlipidemia }\end{array}$ & $3 \mathrm{~g}$ ginger $/ \mathrm{d} ; 45 \mathrm{~d}$ & $(162)$ & Decrease in triglyceride, cholesterol, LDL, VLDL \\
\hline $35 / 35$ healthy participants & $300 / 600 \mathrm{mg} \mathrm{NT}$ (t.w. GA)/d; $24 \mathrm{w}$ & (163) & $\begin{array}{l}\text { Ineffective in causing weight loss or in suppressing } \\
\text { food Intake }\end{array}$ \\
\hline 64 T2DM patients & $2 \mathrm{~g}$ ginger extract $/ \mathrm{d} / 2 \mathrm{~m}$ to NIDDM patients & $(159)$ & $\begin{array}{l}\text { Reduction in HbA1c, HOMA, Improvement in lipid } \\
\text { profile }\end{array}$ \\
\hline 70 T2DM patients & $1.6 \mathrm{~g}$ ginger extract $/ \mathrm{d} / 3 \mathrm{~m}$ to NIDDM patients & (158) & $\begin{array}{l}\text { Reduction in CRP, FBS, HbAlc, HOMA Index, } \\
\text { serum insulin, and improvement in lipid profile }\end{array}$ \\
\hline 41 T2DM patients & $\begin{array}{l}\text { received } 2 \mathrm{~g} / \text { day of ginger powder supplement } \\
\text { or lactose as placebo for } 12 \mathrm{~W}\end{array}$ & $(164)$ & $\begin{array}{l}\text { Reduction in FBS, Hb A1c, apolipoprotein B, } \\
\text { apolipoprotein B/apolipoprotein A-I and MDA, } \\
\text { increase in apolipoprotein A-I }\end{array}$ \\
\hline 88 T2DM patients & $\begin{array}{l}\text { received } 3 \text { one-gram capsules containing gin- } \\
\text { ger powder, whereas the PG received } 3 \text { one- } \\
\text { gram/day microcrystalline-containing capsules } \\
\text { for } 8 \mathrm{w}\end{array}$ & $(165)$ & Decrease in FBS, fasting insulin level, and HOMA. \\
\hline
\end{tabular}

Type 2 diabetes. Table 8 displays recent clinical trials testing ginger with respect to diabetic and inflammatory markers.

\section{Effect of phytochemicals on adipose tissue in-} flammation and diabetes

Adipocytes are the place for energy storage and they produce cytokines including interleukin IL-1 $\beta$, IL-6, TNF- $\alpha$, MCP-1, leptin, adiponectin, and many other molecules; thereby, they are referred to as adipokines. In the context of inflammation, the adipose tissue is infiltrated through macrophages, and it also releases proinflammatory mediators, produces reactive oxygen species, and stimulates T-cell responses for successful defense against invading organisms.

\section{Hypoxia}

Obesity decreases tissue mass access to oxygen (166169). In mitochondria, reactive oxygen species (ROS) production elevates because of hypoxia (170), and consequently, compensatory angiogenesis is induced. This action leads to a reduction of adiponectin expression and secretion and an increase of proangiogenic genes including leptin, IL-6, and the vascular endothelial growth factor (VEGF) by adipocytes (171). It also stimulates expression of IL1 $\beta$, IL- 6 , and TNF- $\alpha$ in macrophages (172). Hence, hypoxia is another key player with the potential to activate such inflammatory cascades in adipose tissue. Evidence for this hypothesis was provided previously when it was shown that hypoxia occurs in the adipose tissue of different obese mouse models and contributes to the endocrine dysregulation (172-174). However, it is unclear whether hypoxia in adipocytes triggers the inflammatory cascade per se without interfering with immune cells or other parameters.

Immune cells are known to invade adipose tissue. In adipose tissue, the interaction of immune cells with adjacent adipocytes increases the inflammation. These cells may also directly induce expression of proinflammatory genes by hypoxia (174-182). Some polyphenols as resveratrol, quercetin, and catechins are present at higher concentrations in red grapes. The balance of con- sumed versus stored energy is represented through the AMP; ATP ratio can be assessed by the AMPK, which plays a central role in the regulation of glucose and lipid metabolism. Its overactivation by high AMP and low ATP levels, respectively, enhances cellular energy levels through suppressing anabolic energy consuming pathways (synthesis of lipids, glucose, and protein) and stimulating energy producing catabolic pathways (the uptake and oxidation of glucose and fat).

One of the important polyphenols mechanisms of action is the activation of PPAR- $\gamma$, which has regulatory effects on metabolism and inflammatory processes.

PPAR $\gamma$ is restricted largely to adipose tissue and, to a much lesser extent, to immune cells. It is an activator of adipogenesis, as it induces fatty acid synthesis and storage, and thus it is likely inhibited by AMPK $(18,183$, 184). Also, PPAR $\gamma$ represses the expression of inflammatory genes as iNOS suppresses transcription factors AP-1 and NF- $\mathrm{kB}$, modulates MAPK activity, and influences glucose uptake (185). Hence, PPAR $\gamma$ is a suitable target for medical intervention, and PPAR $\gamma$-activating pioglitazone is a well-known antidiabetic drug for treatment of T2DM (186).

These pathways are activated in adipose tissue. Also, JNK is activated by insulin but mediates feedback inhibition of insulin signaling, and thus contributes to insulin resistance (187). The insulin/IGF-1 signaling plays a role in developing cancer and T2DM (188). Sugar-rich food in Western diet induces insulin. The resulting insulin/IGF-1 signaling (IIS) activates the phosphatidylinositol 3-kinase (PI3K) and Akt kinase that mediate the suppression of transcription factors of the Forkhead box O (FoxO)(189), which are supposed to prevent uncontrolled inflammatory response (190), indicating a link between Western diet and development of civilization diseases like cancers and T2DM (188).

\section{Conclusion}

In this review, we discussed the effects of polyphenols on blood glucose and diabetes complications and mechanisms of their actions. To answer these questions, we focused on specific food sources rich in dietary polyphenols. 
Interaction of phytochemicals with receptor PPAR $\gamma$ has been shown for resveratrol, genistein, curcumin, capsaicin, catechins, and quercetin however, they had contradictory effects as well (191-193). The phytochemicals were all seemed to activate AMPK or affect inflammatory cascades via proteasomal activation as well as inactivation of key transcription factors, and this may explain most of the properties attributed to PPAR $\gamma$ interaction. Genistein, resveratrol, catechin, quercetin, and curcumin inhibit the respiratory chain and ATP synthetase at the inner mitochondrial membrane $(25,114)$. Overproduction of ROS via the mitochondrial electron transfer chain is the link between several independent molecular mechanisms (AGE formation, the polyol and hexosamine pathway flux, PKC activation and NF- $\kappa \mathrm{B}$ activation) implicated in diabetic side effects (194). Considering the central role of reactive oxygen substances (ROS) (194), the hypoxiainduced ROS production at the mitochondrial electrontransport chain and the subsequent activation of the inflammatory response, it can be stated that polyphenols, as antioxidants, have a beneficial role in improving diabetes side effects (170). Furthermore, comparing traditionally produced food to modern food, phytochemicals may have probably been produced formerly in plants to a much higher amount than in today's industrialized and standardized agricultures because of a lack of stress via pathogens or pests. Thereby, future studies may also take into account different genetic predispositions for some of these compounds if testing their value as a platform for drug development or diet supplements. Animal and human studies have shown that polyphenols, foods, or beverages rich in polyphenols have reduced postprandial and fasting hyperglycemia and improved acute insulin secretion and insulin sensitivity. The possible mechanisms include a decrease in glucose absorption in the intestine and suppression of carbohydrate digestion, stimulation of insulin secretion from the pancreatic $\beta$ cells, modulation of glucose release from the liver, activation of insulin receptors and glucose uptake in the insulin-sensitive tissues, modulation of intracellular signaling pathways, and gene expression. Gut microbiota improvement by polyphenols could be an interesting target for exploring the potential role of polyphenols in metabolic balance and weight loss (195). The positive effects of polyphenols on glucose homeostasis have been found in a large number of in vitro, animal models, and some human trials. To confirm the implications of polyphenol consumption in preventing insulin resistance, Type 2 diabetes, and metabolic syndrome, more human trials with well-defined diets, controlled study designs, and investigation of molecular pathways involved in glucose homeostasis are needed. However, a limitation in clinical studies is the heterogeneous bioavailability and rapid metabolism of polyphenols.

\section{Conflict of Interests}

The authors declare that they have no competing interests.

\section{References}

1. Shi Y, Hu FB. The global implications of diabetes and cancer. Lancet. 2014;383(9933):1947-8.

2. Groop L, Pociot F. Genetics of diabetes-Are we missing the genes or the disease? Mol Cell Endocrinol. 2014;382(1):726-39.

3. Li Z, Geng YN, Jiang JD, Kong WJ. Antioxidant and AntiInflammatory Activities of Berberine in the Treatment of Diabetes Mellitus. Evidence-based Complementary and Alternative Medicine (eCAM) 2014; 2014: 289264.

4. Pandey KB, Rizvi SI. Plant polyphenols as dietary antioxidants in human health and disease. Oxid Med Cell Longev. 2009; 2(5): 270 278.

5. Park KK, Chun KS, Lee JM, Lee SS, Surh YJ. Inhibitory effects of [6]-gingerol, a major pungent principle of ginger, on phorbol esterinduced inflammation, epidermal ornithine decarboxylase activity and skin tumor promotion in ICR mice. Cancer Lett. 1998;129(2):139-44.

6. Duvoix A, Blasius R, Delhalle S, Schnekenburger M, Morceau F, Henry E, et al. Chemopreventive and therapeutic effects of curcumin. Cancer Lett. 2005;223(2):181-90.

7. Shishodia S, Sethi G, Aggarwal BB. Curcumin: getting back to the roots. Ann N Y Acad Sci . 2005;1056(1):206-17.

8. Bae MK, Kim SH, Jeong JW, Lee YM, Kim HS, Kim SR, et al. Curcumin inhibits hypoxia-induced angiogenesis via down-regulation of HIF-1. Oncol Rep.2006;15(6):1557-62.

9. Choi H, Chun YS, Kim SW, Kim MS, Park JW. Curcumin inhibits hypoxia-inducible factor-1 by degrading aryl hydrocarbon receptor nuclear translocator: a mechanism of tumor growth inhibition. Mol Pharmacol. 2006;70(5):1664-71.

10. Ravindran J, Prasad S, Aggarwal BB. Curcumin and cancer cells: how many ways can curry kill tumor cells selectively? The AAPS journal. 2009;11(3):495-510

11. Montopoli M, Ragazzi E, Froldi G, Caparrotta L. Cell-cycle inhibition and apoptosis induced by curcumin and cisplatin or oxaliplatin in human ovarian carcinoma cells. Cell proliferation. 2009;42(2):195-206

12. Jutooru I, Chadalapaka G, Lei P, Safe S. Inhibition of NFkappaB and pancreatic cancer cell and tumor growth by curcumin is dependent on specificity protein down-regulation. J Biol Chem. 2010;285(33):25332-44.

13. Kim CY, Le TT, Chen C, Cheng JX, Kim KH. Curcumin inhibits adipocyte differentiation through modulation of mitotic clonal expansion. J. Nutr. Biochem.. 2011;22(10):910-20.

14. He ZY, Shi CB, Wen H, Li FL, Wang BL, Wang J. Upregulation of p53 expression in patients with colorectal cancer by administration of curcumin. Cancer invest.. 2011;29(3):208-13.

15. Ohara K, Uchida A, Nagasaka R, Ushio H, Ohshima T. The effects of hydroxycinnamic acid derivatives on adiponectin secretion. Phytomedicine. 2009;16(2):130-7.

16. Ikonomov OC, Sbrissa D, Mlak K, Shisheva A. Requirement for PIKfyve enzymatic activity in acute and long-term insulin cellular effects. Endocrinology. 2002;143(12):4742-54.

17. Ahn J, Lee H, Kim S, Ha T. Curcumin-induced suppression of adipogenic differentiation is accompanied by activation of Wnt $/ \beta$ catenin signaling. Am J Physiol Cell Physiol. 2010;298(6):C1510-C6.

18. Lee YK, Lee WS, Hwang JT, Kwon DY, Surh YJ, Park OJ. Curcumin exerts antidifferentiation effect through AMPKalphaPPAR-gamma in 3T3-L1 adipocytes and antiproliferatory effect through AMPKalpha-COX-2 in cancer cells. J Agric Food Chem. 2009;57(1):305-10.

19. Cho JW, Lee KS, Kim CW. Curcumin attenuates the expression of IL-1beta, IL-6, and TNF-alpha as well as cyclin E in TNF-alphatreated HaCaT cells; NF-kappaB and MAPKs as potential upstream targets. Int J Mol Med. 2007;19(3):469-74.

20. Kim JH, Park SH, Nam SW, Kwon HJ, Kim BW, Kim WJ, et al. Curcumin stimulates proliferation, stemness acting signals and migration of 3T3-L1 preadipocytes. Int J Mol Med. 2011;28(3):42935.

21. Zhao J, Sun XB, Ye F, Tian WX. Suppression of fatty acid synthase, differentiation and lipid accumulation in adipocytes by curcumin. Mol Cell Biochem. 2011;351(1-2):19-28.

22. Jacob A, Wu R, Zhou M, Wang P. Mechanism of the Antiinflammatory Effect of Curcumin: PPAR-gamma Activation. PPAR Res. 2007;2007:89369. 
23. Narala VR, Smith MR, Adapala RK, Ranga R, Panati K, Moore BB, et al. Curcumin is not a ligand for peroxisome proliferator-activated receptor- $\gamma$. Gene therapy \& molecular biology. 2009;13(1):20.

24. Dong SZ, Zhao SP, Wu ZH, Yang J, Xie XZ, Yu BL, et al. Curcumin promotes cholesterol efflux from adipocytes related to PPARgamma-LXRalpha-ABCA1 passway. Mol Cell Biochem. 2011;358(1-2):281-5.

25. Zheng J, Ramirez VD. Inhibition of mitochondrial proton F0F1-ATPase/ATP synthase by polyphenolic phytochemicals. Br J Pharmacol. 2000;130(5):1115-23.

26. Woo HM, Kang JH, Kawada T, Yoo H, Sung MK, Yu R. Active spice-derived components can inhibit inflammatory responses of adipose tissue in obesity by suppressing inflammatory actions of macrophages and release of monocyte chemoattractant protein- 1 from adipocytes. Life sciences. 2007;80(10):926-31.

27. Seo KI, Choi MS, Jung UJ, Kim HJ, Yeo J, Jeon SM, et al. Effect of curcumin supplementation on blood glucose, plasma insulin, and glucose homeostasis related enzyme activities in diabetic $\mathrm{db} / \mathrm{db}$ mice. Mol Nutr Food Res. 2008;52(9):995-1004.

28. Nishiyama T, Mae T, Kishida H, Tsukagawa M, Mimaki Y, Kuroda $\mathrm{M}$, et al. Curcuminoids and sesquiterpenoids in turmeric (Curcuma longa L.) suppress an increase in blood glucose level in Type 2 diabetic KK-Ay mice. J Agric Food Chem. 2005;53(4):959-63.

29. Weisberg SP, Leibel R, Tortoriello DV. Dietary curcumin significantly improves obesity-associated inflammation and diabetes in mouse models of diabesity. Endocrinology. 2008;149(7):3549-58.

30. Ejaz A, Wu D, Kwan P, Meydani M. Curcumin inhibits adipogenesis in 3T3-L1 adipocytes and angiogenesis and obesity in C57/BL mice. J Nutr. 2009;139(5):919-25.

31. Asai A, Miyazawa T. Dietary curcuminoids prevent high-fat dietinduced lipid accumulation in rat liver and epididymal adipose tissue. J Nutr. 2001;131(11):2932-5.

32. Pari L, Murugan P. Antihyperlipidemic effect of curcumin and tetrahydrocurcumin in experimental Type 2 diabetic rats. Ren fail. 2007;29(7):881-9.

33. Jang EM, Choi MS, Jung UJ, Kim MJ, Kim HJ, Jeon SM, et al. Beneficial effects of curcumin on hyperlipidemia and insulin resistance in high-fat-fed hamsters. Metabolism. 2008;57(11):157683.

34. Kim T, Davis J, Zhang AJ, He X, Mathews ST. Curcumin activates AMPK and suppresses gluconeogenic gene expression in hepatoma cells. Biochem Biophys Res Commun. 2009;388(2):377-82.

35. Chuengsamarn S, Rattanamongkolgul S, Luechapudiporn $\mathrm{R}$, Phisalaphong C, Jirawatnotai S. Curcumin extract for prevention of Type 2 diabetes. Diabetes Care. 2012;35(11):2121-7.

36. Appendino G, Belcaro G, Cornelli U, Luzzi R, Togni S, Dugall M, et al. Potential role of curcumin phytosome (Meriva) in controlling the evolution of diabetic microangiopathy. A pilot study. Panminerva medica. 2011;53(3 Suppl 1):43-9.

37. Pungcharoenkul K, Thongnopnua P. Effect of different curcuminoid supplement dosages on total in vivo antioxidant capacity and cholesterol levels of healthy human subjects. Phytother Res. 2011;25(11):1721-6.

38. Khajehdehi P, Pakfetrat M, Javidnia K, Azad F, Malekmakan L, Nasab MH, et al. Oral supplementation of turmeric attenuates proteinuria, transforming growth factor- $\beta$ and interleukin- 8 levels in patients with overtType 2 diabetic nephropathy: a randomized, double-blind and placebo-controlled study. Scand J Urol Nephrol. 2011;45(5):365-70

39. Belcaro G, Cesarone MR, Dugall M, Pellegrini L, Ledda A, Grossi MG, et al. Efficacy and safety of Meriva ${ }^{\circledR}$, a curcuminphosphatidylcholine complex, during extended administration in osteoarthritis patients. Altern Med Rev. 2010;15(4):337-44.

40. Kalpravidh RW, Siritanaratkul N, Insain P, Charoensakdi R, Panichkul N, Hatairaktham $\mathrm{S}$, et al. Improvement in oxidative stress and antioxidant parameters in $\beta$-thalassemia/Hb E patients treated with curcuminoids. Clin Biochem. 2010;43(4):424-9.

41. Alwi I, Santoso T, Suyono S, Sutrisna B, Suyatna FD, Kresno SB, et al. The effect of curcumin on lipid level in patients with acute coronary syndrome. Acta Med Indones. 2008;40(4):201-10.

42. Baum L, Cheung SK, Mok VC, Lam LC, Leung VP, Hui E, et al. Curcumin effects on blood lipid profile in a 6-month human study. Pharmacol Res. 2007;56(6):509-14.

43. Selvi NMK, Sridhar M, Swaminathan R, Sripradha R. Efficacy of Turmeric as Adjuvant Therapy in Type 2 Diabetic Patients. Indian
Journal of Clin Biochem. 2014:1-7.

44. Pervaiz S. Resveratrol: from grapevines to mammalian biology. The FASEB journal. 2003;17(14):1975-85.

45. Mark L, Nikfardjam MSP, Avar P, Ohmacht R. A validated HPLC method for the quantitative analysis of trans-resveratrol and transpiceid in Hungarian wines. J Chromatogr Sci. 2005;43(9):445-9.

46. Rouse M, Younès A, Egan JM. Resveratrol and curcumin enhance pancreatic $\beta$-cell function by inhibiting phosphodiesterase activity. J Endocrinol . 2014;223(2):107-17.

47. Timmers S, Konings E, Bilet L, Houtkooper RH, van de Weijer T, Goossens $\mathrm{GH}$, et al. Calorie restriction-like effects of 30 days of resveratrol supplementation on energy metabolism and metabolic profile in obese humans. Cell Metab. 2011;14(5):612-22.

48. Brasnyó P, Molnár GA, Mohás M, Markó L, Laczy B, Cseh J, et al. Resveratrol improves insulin sensitivity, reduces oxidative stress and activates the Akt pathway in Type 2 diabetic patients. Br J Nutr. 2011;106(03):383-9.

49. Brown VA, Patel KR, Viskaduraki M, Crowell JA, Perloff M, Booth $\mathrm{TD}$, et al. Repeat dose study of the cancer chemopreventive agent resveratrol in healthy volunteers: safety, pharmacokinetics, and effect on the insulin-like growth factor axis. Cancer Res. 2010;70(22):900311.

50. Ghanim H, Sia CL, Abuaysheh S, Korzeniewski K, Patnaik P, Marumganti A, et al. An antiinflammatory and reactive oxygen species suppressive effects of an extract of Polygonum cuspidatum containing resveratrol. J Clin Endocrinol Metab 2010;95(9):E1-E8.

51. Davis PA, Yokoyama W. Cinnamon intake lowers fasting blood glucose: meta-analysis. J Med Food . 2011;14(9):884-9.

52. Hlebowicz J, Darwiche G, Björgell O, Almér L-O. Effect of cinnamon on postprandial blood glucose, gastric emptying, and satiety in healthy subjects. Am J Clin Nutr 2007;85(6):1552-6.

53. Caterina MJ, Schumacher MA, Tominaga M, Rosen TA, Levine JD, Julius D. The capsaicin receptor: a heat-activated ion channel in the pain pathway. Nature. 1997;389(6653):816-24.

54. Hwang JT, Park IJ, Shin JI, Lee YK, Lee SK, Baik HW, et al. Genistein, EGCG, and capsaicin inhibit adipocyte differentiation process via activating AMP-activated protein kinase. Biochem Biophys Res Commun. 2005;338(2):694-9.

55. Kim CS, Kawada T, Kim BS, Han IS, Choe SY, Kurata T, et al. Capsaicin exhibits anti-inflammatory property by inhibiting IkB-a degradation in LPS-stimulated peritoneal macrophages. Cellular signalling. 2003;15(3):299-306.

56. Park JY, Kawada T, Han IS, Kim BS, Goto T, Takahashi N, et al. Capsaicin inhibits the production of tumor necrosis factor alpha by LPS-stimulated murine macrophages, RAW 264.7: a PPARgamma ligand-like action as a novel mechanism. FEBS Lett. 2004;572(13):266-70.

57. Kang JH, Kim CS, Han IS, Kawada T, Yu R. Capsaicin, a spicy component of hot peppers, modulates adipokine gene expression and protein release from obese-mouse adipose tissues and isolated adipocytes, and suppresses the inflammatory responses of adipose tissue macrophages. FEBS letters. 2007;581(23):4389-96.

58. Mueller M, Beck V, Jungbauer A. PPAR $\alpha$ activation by culinary herbs and spices. Planta Medica-Natural Products and Medicinal Plant Research. 2011;77(5):497.

59. Osaka T, Kobayashi A, Namba Y, Ezaki O, Inoue S, Kimura S, et al. Temperature-and capsaicin-sensitive nerve fibers in brown adipose tissue attenuate thermogenesis in the rat. Pflügers Archiv. 1998;437(1):36-42.

60. Diepvens K, Westerterp KR, Westerterp-Plantenga MS. Obesity and thermogenesis related to the consumption of caffeine, ephedrine, capsaicin, and green tea. American Am J Physiol Regul Integr Comp Physiol. 2007;292(1):R77-R85.

61. Lee MS, Kim CT, Kim IH, Kim Y. Effects of Capsaicin on Lipid Catabolism in 3T3-L1 Adipocytes. Phytother Res. 2011;25(6):935-9.

62. Zhang LL, Liu DY, Ma LQ, Luo ZD, Cao TB, Zhong J, et al Activation of transient receptor potential vanilloid type-1 channel prevents adipogenesis and obesity. Circ Res. 2007;100(7):1063-70.

63. Kawada T, Hagihara K, Iwai K. Effects of capsaicin on lipid metabolism in rats fed a high fat diet. J Nutr. 1986;116(7):1272-8.

64. Kawada T, Watanabe T, Takaishi T, Tanaka T, Iwai K. Capsaicininduced $\beta$-adrenergic action on energy metabolism in rats: influence of capsaicin on oxygen consumption, the respiratory quotient, and substrate utilization. Exp Biol Med . 1986;183(2):250-6.

65. Kang JH, Tsuyoshi G, Le Ngoc H, Kim HM, Tu TH, Noh HJ, et al. 
Dietary capsaicin attenuates metabolic dysregulation in genetically obese diabetic mice. J Med Food. 2011;14(3):310-5.

66. Lejeune MP, Kovacs EM, Westerterp-Plantenga MS. Effect of capsaicin on substrate oxidation and weight maintenance after modest body-weight loss in human subjects. Br J Nutr. 2003;90(03):651-9.

67. Yoshioka M, Imanaga M, Ueyama H, Yamane M, Kubo Y, Boivin A, et al. Maximum tolerable dose of red pepper decreases fat intake independently of spicy sensation in the mouth. $\mathrm{Br} \mathrm{J}$ Nutr. 2004;91(06):991-5.

68. Chaiyasit K, Khovidhunkit W, Wittayalertpanya S. Pharmacokinetic and the effect of capsaicin in Capsicum frutescens on decreasing plasma glucose level. J Med Assoc Thai. 2009;92(1):108-13.

69. Yoneshiro T, Aita S, Kawai Y, Iwanaga T, Saito M. Nonpungent capsaicin analogs (capsinoids) increase energy expenditure through the activation of brown adipose tissue in humans. Am J Clin Nutr 2012;95(4):845-50

70. Ludy MJ, Mattes RD. The effects of hedonically acceptable red pepper doses on thermogenesis and appetite. Physiol. Behav. 2011;102(3):251-8

71. Reinbach HC, Smeets A, Martinussen T, Møller P, WesterterpPlantenga M. Effects of capsaicin, green tea and $\mathrm{CH}-19$ sweet pepper on appetite and energy intake in humans in negative and positive energy balance. Clinical nut. 2009;28(3):260-5.

72. Ahuja K, Robertson I, Geraghty D, Ball M. The effect of 4-week chilli supplementation on metabolic and arterial function in humans. Eur J Clin Nutr. 2006;61(3):326-33

73. Dömötör A, Szolcsányi J, Mózsik G. Capsaicin and glucose absorption and utilization in healthy human subjects. Eur. J. Pharmacol. 2006;534(1):280-3.

74. Ahuja KD, Ball MJ. Effects of daily ingestion of chilli on serum lipoprotein oxidation in adult men and women. $\mathrm{Br} \mathrm{J}$ Nutr. 2006;96(02):239-42.

75. Ahuja KD, Robertson IK, Geraghty DP, Ball MJ. Effects of chili consumption on postprandial glucose, insulin, and energy metabolism. Am J Clin Nutr 2006;84(1):63-9.

76. Hollenberg NK. Vascular action of cocoa flavanols in humans: the roots of the story. J Cardiovasc Pharmacol. 2006;47:S99-S102.

77. Chacón MR, Ceperuelo-Mallafré V, Maymó-Masip E, Mateo-Sanz JM, Arola L, Guitiérrez C, et al. Grape-seed procyanidins modulate inflammation on human differentiated adipocytes $<\mathrm{i}>$ in vitro $</ \mathrm{i}>$. Cytokine. 2009;47(2):137-42.

78. Yang HY, Yang SC, Chao JCJ, Chen JR. Beneficial effects of catechin-rich green tea and inulin on the body composition of overweight adults. Br J Nutr. 2012;107(05):749-54.

79. Brown A, Lane J, Holyoak C, Nicol B, Mayes A, Dadd T. Health effects of green tea catechins in overweight and obese men: a randomised controlled cross-over trial. Br J Nutr. 2011;106(12):18809.

80. Hua C, Liao Y, Lin S, Tsai T, Huang C, Chou P. Does supplementation with green tea extract improve insulin resistance in obese Type 2 diabetics? A randomized, double-blind, and placebocontrolled clinical trial. Altern Med Rev. 2011;16(2):157-63.

81. Baer D, Novotny J, Harris G, Stote K, Clevidence B, Rumpler W. Oolong tea does not improve glucose metabolism in non-diabetic adults. Eur J Clin Nutr. 2010;65(1):87-93.

82. Lonac MC, Richards JC, Schweder MM, Johnson TK, Bell C. Influence of short-term consumption of the caffeine-free, epigallocatechin-3-gallate supplement, Teavigo, on resting metabolism and the thermic effect of feeding. Obesity. 2011;19(2):298-304.

83. Takahashi M, Miyashita M, Suzuki K, Bae S-r, Kim H-K, Wakisaka $\mathrm{T}$, et al. Acute ingestion of catechin-rich green tea improves postprandial glucose status and increases serum thioredoxin concentrations in postmenopausal women. $\mathrm{Br} \mathrm{J}$ Nutr. 2014;112(09):1542-50.

84. Basu A, Du M, Sanchez K, Leyva MJ, Betts NM, Blevins S, et al. Green tea minimally affects biomarkers of inflammation in obese subjects with metabolic syndrome. Nutrition. 2011;27(2):206-13.

85. Basu A, Sanchez K, Leyva MJ, Wu M, Betts NM, Aston CE, et al. Green tea supplementation affects body weight, lipids, and lipid peroxidation in obese subjects with metabolic syndrome. J Am Coll Nutr. 2010;29(1):31-40.

86. Wang H, Wen Y, Du Y, Yan X, Guo H, Rycroft JA, et al. Effects of catechin enriched green tea on body composition. Obesity. 2010;18(4):773-9.
87. Thielecke F, Rahn G, Böhnke J, Adams F, Birkenfeld AL, Jordan J, et al. Epigallocatechin-3-gallate and postprandial fat oxidation in overweight/obese male volunteers: a pilot study. Eur J Clin Nutr. 2010;64(7):704-13.

88. Oyama JI, Maeda T, Kouzuma K, Ochiai R, Tokimitsu I, Higuchi Y, et al. Green tea catechins improve human forearm endothelial dysfunction and have antiatherosclerotic effects in smokers. Circ J .2010;74(3):578-88.

89. Agarwal A, Prasad R, Jain A. Effect of green tea extract (catechins) in reducing oxidative stress seen in patients of pulmonary tuberculosis on DOTS Cat I regimen. Phytomedicine. 2010;17(1):23-

90. Brown AL, Lane J, Coverly J, Stocks J, Jackson S, Stephen A, et al. Effects of dietary supplementation with the green tea polyphenol epigallocatechin-3-gallate on insulin resistance and associated metabolic risk factors: randomized controlled trial. $\mathrm{Br} \mathrm{J}$ Nutr. 2009;101(06):886-94

91. Nagao T, Meguro S, Hase T, Otsuka K, Komikado M, Tokimitsu I, et al. A Catechin-rich Beverage Improves Obesity and Blood Glucose Control in Patients With Type 2 Diabetes. Obesity. 2009;17(2):310-7.

92. Matsuyama T, Tanaka Y, Kamimaki I, Nagao T, Tokimitsu I. Catechin safely improved higher levels of fatness, blood pressure, and cholesterol in children. Obesity. 2008;16(6):1338-48.

93. Venables MC, Hulston CJ, Cox HR, Jeukendrup AE. Green tea extract ingestion, fat oxidation, and glucose tolerance in healthy humans. Am J Clin Nutr. 2008;87(3):778-84.

94. Fukino Y, Ikeda A, Maruyama K, Aoki N, Okubo T, Iso H. Randomized controlled trial for an effect of green tea-extract powder supplementation on glucose abnormalities. Eur J Clin Nutr. 2007;62(8):953-60.

95. Inami S, Takano M, Yamamoto M, Murakami D, Tajika K, Yodogawa K, et al. Tea catechin consumption reduces circulating oxidized low-density lipoprotein. Int Heart J . 2007;48(6):725-32.

96. MacKenzie T, Leary L, Brooks WB. The effect of an extract of green and black tea on glucose control in adults with Type 2 diabetes mellitus: double-blind randomized study. Metabolism. 2007;56(10):1340-4

97. Hill AM, Coates AM, Buckley JD, Ross R, Thielecke F, Howe PR. Can EGCG reduce abdominal fat in obese subjects? J Am Coll Nutr. 2007;26(4):396S-402S.

98. Boschmann M, Thielecke F. The effects of epigallocatechin-3gallate on thermogenesis and fat oxidation in obese men: a pilot study. J Am Coll Nutr. 2007;26(4):389S-95S

99. Yin J, Xing H, Ye J. Efficacy of berberine in patients with Type 2 diabetes mellitus. Metabolism. 2008;57(5):712-7.

100. Dong H, Wang N, Zhao L, Lu F. Berberine in the treatment of Type 2 diabetes mellitus: a systemic review and meta-analysis. Evid Based Complement Alternat Med. 2012;2012:591654.

101. Shidfar F, Ebrahimi SS, Hosseini S, Heydari I, Shidfar S, Hajhassani G. The effects of Berberis vulgaris fruit extract on serum lipoproteins, apoB, apoA-I, homocysteine, glycemic control and total antioxidant capacity in Type 2 diabetic patients. Iranian journal of pharmaceutical research: IJPR. 2012;11(2):643.

102. Di Pierro F, Putignano P, Villanova N, Montesi L, Moscatiello S, Marchesini G. Preliminary study about the possible glycemic clinical advantage in using a fixed combination of Berberis aristata and Silybum marianum standardized extracts versus only Berberis aristata in patients with Type 2 diabetes. Clin Pharmacol. 2013;5:167.

103. Moazezi Z, Qujeq D. Berberis Fruit Extract and Biochemical Parameters in Patients With Type II Diabetes. JUNDISHAPUR J NAT PHARM PROD. 2014;9(2).

104. Severson RK, Nomura AM, Grove JS, Stemmermann GN. A prospective study of demographics, diet, and prostate cancer among men of Japanese ancestry in Hawaii. Cancer Res. 1989;49(7):185760 .

105. Muir C, Waterhouse JAH, Mack T, Powell J, Whelan S. Cancer Incidence in Five Continents IARC Scientific Publications 1987; V.

106. Odegaard AO, Koh WP, Butler LM, Duval S, Gross MD, Mimi CY, et al. Dietary Patterns and Incident Type 2 Diabetes in Chinese Men and Women The Singapore Chinese Health Study. Diabetes care. 2011;34(4):880-5.

107. Wang B, Li H, Yan H, Xiao J. Genistein inhibited hypoxiainducible factor-1alpha expression induced by hypoxia and cobalt chloride in human retinal pigment epithelium cells. Methods Find Exp Clin Pharmacol. 2005;27(3):179-84. 
108. Li Z, Ya K, Xiao-Mei W, Lei Y, Yang L, Ming QZ. Ginkgolides protect PC12 cells against hypoxia-induced injury by p42/p44 MAPK pathway-dependent upregulation of HIF-1 $\alpha$ expression and HIF-1DNA-binding activity. J cell biochem. 2008;103(2):564-75.

109. Li Y, Zhang JF, Zhang YM, Ma XB. The protective effect of genistein postconditioning on hypoxia/reoxygenation-induced injury in human gastric epithelial cells. Acta Pharmacologica Sinica. 2009;30(5):576-81.

110. Relic B, Zeddou M, Desoroux A, Beguin Y, de Seny D, Malaise MG. Genistein induces adipogenesis but inhibits leptin induction in human synovial fibroblasts. Lab Invest. 2009;89(7):811-22.

111. Hirota K, Morikawa K, Hanada H, Nonaka M, Nakajima Y, Kobayashi M, et al. Effect of genistein and daidzein on the proliferation and differentiation of human preadipocyte cell line. J Agric Food Chem. 2010;58(9):5821-7.

112. Szkudelska K, Nogowski L, Szkudelski T. Genistein, a plantderived isoflavone, counteracts the antilipolytic action of insulin in isolated rat adipocytes. $\mathrm{J}$ Steroid Biochem Mol Biol. 2008;109(1):108-14.

113. Dang ZC, Audinot V, Papapoulos SE, Boutin JA, Lowik CW. Peroxisome proliferator-activated receptor gamma (PPARgamma ) as a molecular target for the soy phytoestrogen genistein. J Biol Chem. 2003;278(2):962-7.

114. Szkudelska K, Nogowski L, Szkudelski T. Genistein affects lipogenesis and lipolysis in isolated rat adipocytes. J Steroid Biochem Mol Biol 2000;75(4):265-71.

115. Harmon AW, Harp JB. Differential effects of flavonoids on 3T3$\mathrm{L} 1$ adipogenesis and lipolysis. Am $\mathrm{J}$ of Physiol-Cell Physiol. 2001;280(4):C807-C13.

116. Linford NJ, Yang Y, Cook DG, Dorsa DM. Neuronal apoptosis resulting from high doses of the isoflavone genistein: role for calcium and p42/44 mitogen-activated protein kinase. J Pharmacol Exp Ther. 2001;299(1):67-75

117. Lee YM, Choi JS, Kim MH, Jung MH, Lee YS, Song J. Effects of dietary genistein on hepatic lipid metabolism and mitochondrial function in mice fed high-fat diets. Nutrition. 2006;22(9):956-64.

118. Park HJ, Della-Fera MA, Hausman DB, Rayalam S, Ambati S, Baile CA. Genistein inhibits differentiation of primary human adipocytes. J Nutr Biochem. 2009;20(2):140-8.

119. Cho HY, Park CM, Kim MJ, Chinzorig R, Cho CW, Song YS, Comparative effect of genistein and daidzein on the expression of MCP-1, eNOS, and cell adhesion molecules in TNF- $\alpha$-stimulated HUVECs. Nutr Res Pract. 2011;5(5):381-8.

120. Baluchnejadmojarad T, Roghani M. Chronic administration of genistein improves aortic reactivity of streptozotocin-diabetic rats: mode of action. Vasc Pharmacol. 2008;49(1):1-5.

121. Kim MH, Kang KS, Lee YS. The inhibitory effect of genistein on hepatic steatosis is linked to visceral adipocyte metabolism in mice with diet-induced non-alcoholic fatty liver disease. $\mathrm{Br} \mathrm{J}$ Nutr. 2010;104(9):1333-42.

122. Szkudelska K, Nogowski L, Szkudelski T. Resveratrol and genistein as adenosine triphosphate-depleting agents in fat cells. Metabolism. 2011;60(5):720-9.

123. Lazarevic B, Boezelijn G, Diep LM, Kvernrod K, Ogren O, Ramberg $\mathrm{H}$, et al. Efficacy and safety of short-term genistein intervention in patients with localized prostate cancer prior to radical prostatectomy: a randomized, placebo-controlled, double-blind Phase 2 clinical trial. Nutr Cancer. 2011;63(6):889-98.

124. Llaneza P, González C, Fernandez-Iñarrea J, Alonso A, Diaz F, Arnott I, et al. Soy isoflavones, diet and physical exercise modify serum cytokines in healthy obese postmenopausal women. Phytomedicine. 2011;18(4):245-50.

125. Marini H, Bitto A, Altavilla D, Burnett BP, Polito F, Di Stefano V, et al. Efficacy of genistein aglycone on some cardiovascular risk factors and homocysteine levels: A follow-up study. Nutr Metab Cardiovasc Dis. 2010;20(5):332-40.

126. Villa $\mathrm{P}$, Costantini $\mathrm{B}$, Suriano R, Perri $\mathrm{C}$, Macrì $\mathrm{F}$, Ricciardi L, et al. The differential effect of the phytoestrogen genistein on cardiovascular risk factors in postmenopausal women: relationship with the metabolic status. J Clin Endocrinol Metab. 2009; 94(2):5528.

127. Charles C, Yuskavage J, Carlson O, John M, Tagalicud AS, Maggio M, et al. Effects of high-dose isoflavones on metabolic and inflammatory markers in healthy postmenopausal women. Menopause (New York, NY). 2009;16(2):395.
128. Rios DRA, Rodrigues ET, Cardoso APZ, Montes MBA, Franceschini SA, Toloi MRT. Lack of effects of isoflavones on the lipid profile of Brazilian postmenopausal women. Nutrition. 2008;24(11):1153-8

129. Mouria M, Gukovskaya AS, Jung Y, Buechler P, Hines OJ, Reber HA, et al. Food-derived polyphenols inhibit pancreatic cancer growth through mitochondrial cytochrome $\mathrm{C}$ release and apoptosis. Int $\mathrm{J}$ Cancer . 2002;98(5):761-9.

130. Yang JY, Della-Fera MA, Rayalam S, Ambati S, Hartzell DL, Park $\mathrm{HJ}$, et al. Enhanced inhibition of adipogenesis and induction of apoptosis in 3T3-L1 adipocytes with combinations of resveratrol and quercetin. Life Sci. 2008;82(19-20):1032-9.

131. Rayalam S, Della-Fera MA, Yang JY, Park HJ, Ambati S, Baile CA. Resveratrol potentiates genistein's antiadipogenic and proapoptotic effects in 3T3-L1 adipocytes. J Nutr. 2007;137(12):2668-73

132. Park HJ, Yang J-Y, Ambati S, Della-Fera MA, Hausman DB, Rayalam S, et al. Combined effects of genistein, quercetin, and resveratrol in human and 3T3-L1 adipocytes. J Med Food. 2008;11(4):773-83.

133. Konrad M, Nieman DC, Henson DA, Kennerly KM, Jin F, Wallner-Liebmann SJ. The acute effect of ingesting a quercetin-based supplement on exercise-induced inflammation and immune changes in runners. Int J Sport Nutr Exerc Metab . 2011;21(4):338.

134. Knab AM, Shanely RA, Henson DA, Jin F, Heinz SA, Austin MD, et al. Influence of quercetin supplementation on disease risk factors in community-dwelling adults. J Am Diet Assoc . 2011;111(4):542-9.

135. Boots AW, Drent M, de Boer VC, Bast A, Haenen GR. Quercetin reduces markers of oxidative stress and inflammation in sarcoidosis. Clin Nutr . 2011;30(4):506-12.

136. Egert S, Rimbach G, Müller MJ. No evidence for a thermic effect of the dietary flavonol quercetin: a pilot study in healthy normalweight women. Eur J Appl Physiol. 2011;111(5):869-73.

137. Heinz SA, Henson DA, Nieman DC, Austin MD, Jin F. A 12-week supplementation with quercetin does not affect natural killer cell activity, granulocyte oxidative burst activity or granulocyte phagocytosis in female human subjects. Br J Nutr. 2010;104(06):84957.

138. Egert S, Boesch-Saadatmandi C, Wolffram S, Rimbach G, Müller MJ. Serum lipid and blood pressure responses to quercetin vary in overweight patients by apolipoprotein $\mathrm{E}$ genotype. J Nutr. 2010;140(2):278-84

139. Bae SC, Jung WJ, Lee EJ, Yu R, Sung MK. Effects of antioxidant supplements intervention on the level of plasma inflammatory molecules and disease severity of rheumatoid arthritis patients. J Am Coll Nutr. 2009;28(1):56-62

140. Egert S, Bosy-Westphal A, Seiberl J, Kürbitz C, Settler U, PlachtaDanielzik $\mathrm{S}$, et al. Quercetin reduces systolic blood pressure and plasma oxidised low-density lipoprotein concentrations in overweigh subjects with a high-cardiovascular disease risk phenotype: a doubleblinded, placebo-controlled cross-over study. $\mathrm{Br} \quad \mathrm{J}$ Nutr. 2009;102(07):1065-74

141. Egert S, Wolffram S, Bosy-Westphal A, Boesch-Saadatmandi C, Wagner AE, Frank J, et al. Daily quercetin supplementation dosedependently increases plasma quercetin concentrations in healthy humans. J Nutr. 2008;138(9):1615-21.

142. Mazloom Z, Abdollahzadeh SM, Dabbaghmanesh $\mathrm{MH}$ Rezaianzadeh A. The Effect of Quercetin Supplementation on Oxidative Stress, Glycemic Control, Lipid Profile and Insulin Resistance in Type 2 Diabetes: A Randomized Clinical Trial. J. Health Sci. Surveill. Syst. 2014;2(1):8-14.

143. Ojewole JA. Analgesic, antiinflammatory and hypoglycaemic effects of ethanol extract of Zingiber officinale (Roscoe) rhizomes (Zingiberaceae) in mice and rats. Phytother Res. 2006;20(9):764-72.

144. Jiang H, Xie Z, Koo HJ, McLaughlin SP, Timmermann BN, Gang DR. Metabolic profiling and phylogenetic analysis of medicinal $<\mathrm{i}>$ Zingiber $</ \mathrm{i}>$ species: Tools for authentication of ginger $(<\mathrm{i}>$ Zingiber officinale $</ i>$ Rosc.). Phytochemistry. 2006;67(15):167385.

145. Lu J, Guan S, Shen X, Qian W, Huang G, Deng X, et al. Immunosuppressive activity of 8 -gingerol on immune responses in mice. Molecules. 2011;16(3):2636-45.

146. Kim SO, Kundu JK, Shin YK, Park JH, Cho MH, Kim TY, et al. [6]-Gingerol inhibits COX-2 expression by blocking the activation of p38 MAP kinase and NF-kappaB in phorbol ester-stimulated mouse 
skin. Oncogene. 2005;24(15):2558-67.

147. Surh YJ, Park KK, Chun KS, Lee L, Lee E, Lee SS. Anti-tumorpromoting activities of selected pungent phenolic substances present in ginger. Journal of environmental pathology, toxicology and oncology: J Environ Pathol Toxicol Oncol . 1998;18(2):131-9.

148. Yon JM, Baek IJ, Lee BJ, Yun YW, Nam SY. Emodin and [6] gingerol lessen hypoxia-induced embryotoxicities in cultured mouse whole embryos via upregulation of hypoxia-inducible factor $1 \alpha$ and intracellular superoxide dismutases. Reprod Toxicol. 2011;31(4):5138.

149. Isa Y, Miyakawa Y, Yanagisawa M, Goto T, Kang MS, Kawada T, et al. 6-Shogaol and 6-gingerol, the pungent of ginger, inhibit TNFalpha mediated downregulation of adiponectin expression via different mechanisms in 3T3-L1 adipocytes. Biochem Biophys Res Commun. 2008;373(3):429-34.

150. Sekiya K, Ohtani A, Kusano S. Enhancement of insulin sensitivity in adipocytes by ginger. Biofactors. 2004;22(1-4):153-6.

151. Dedov VN, Tran VH, Duke CC, Connor M, Christie MJ, Mandadi $\mathrm{S}$, et al. Gingerols: a novel class of vanilloid receptor (VR1) agonists. Br J Pharmacol . 2002;137(6):793-8.

152. Eldershaw T, Colquhoun E, Dora K, Peng ZC, Clark M. Pungent principles of ginger (Zingiber officinale) are thermogenic in the perfused rat hindlimb. International journal of obesity and related metabolic disorders: Obes Rev. 1992;16(10):755-63.

153. Islam MS, Choi H. Comparative effects of dietary ginger (Zingiber officinale) and garlic (Allium sativum) investigated in a Type 2 diabetes model of rats. J Med Food . 2008;11(1):152-9.

154. Al-Amin ZM, Thomson M, Al-Qattan KK, Peltonen-Shalaby R, Ali M. Anti-diabetic and hypolipidaemic properties of ginger (Zingiber officinale) in streptozotocin-induced diabetic rats. $\mathrm{Br} \mathrm{J}$ Nutr. 2006;96(04):660-6.

155. Beattie JH, Nicol F, Gordon MJ, Reid MD, Cantlay L, Horgan $\mathrm{GW}$, et al. Ginger phytochemicals mitigate the obesogenic effects of a high-fat diet in mice: A proteomic and biomarker network analysis. Mol Nutr Food Res. 2011;55(S2):S203-S13.

156. Ramudu SK, Korivi M, Kesireddy N, Lee L-C, Cheng I-S, Kuo C$\mathrm{H}$, et al. Nephro-protective effects of a ginger extract on cytosolic and mitochondrial enzymes against streptozotocin (STZ)-induced diabetic complications in rats. Chin J Physiol. 2011;54(2):79-86.

157. Yu Y, Zick S, Li X, Zou P, Wright B, Sun D. Examination of the pharmacokinetics of active ingredients of ginger in humans. The AAPS journal. 2011;13(3):417-26.

158. Arablou T, Aryaeian N, Valizadeh M, Sharifi F, Hosseini A, Djalali M. The effect of ginger consumption on glycemic status, lipid profile and some inflammatory markers in patients with Type 2 diabetes mellitus. Int J Food Sci Nutr. 2014;65(4):515-20.

159. Mahluji S, Attari VE, Mobasseri M, Payahoo L, Ostadrahimi A, Golzari SE. Effects of ginger (Zingiber officinale) on plasma glucose level, HbA1c and insulin sensitivity in Type 2 diabetic patients. Int $\mathrm{J}$ Food Sci Nutr. 2013;64(6):682-6.

160. Bordia A, Verma SK, Srivastava KC. Effect of ginger (Zingiber officinale Rosc.) and fenugreek (Trigonella foenumgraecum L.) on blood lipids, blood sugar and platelet aggregation in patients with coronary artery disease. Prostaglandins Leukot Essent Fatty Acids. 1997;56(5):379-84.

161. Zick SM, Turgeon DK, Vareed SK, Ruffin MT, Litzinger AJ, Wright BD, et al. Phase II study of the effects of ginger root extract on eicosanoids in colon mucosa in people at normal risk for colorectal cancer. Cancer Prev Res. 2011;4(11):1929-37.

162. Alizadeh-Navaei R, Roozbeh F, Saravi M, Pouramir M, Jalali F, Moghadamnia AA. Investigation of the effect of ginger on the lipid levels. A double blind controlled clinical trial. Saudi Med J. 2008;29(9):1280-4.

163. Roberts AT, Martin CK, Liu Z, Amen RJ, Woltering EA, Rood JC, et al. The safety and efficacy of a dietary herbal supplement and gallic acid for weight loss. J Med Food . 2007;10(1):184-8.

164. Khandouzi N, Shidfar F, Rajab A, Rahideh T, Hosseini P, Taheri MM. The Effects of Ginger on Fasting Blood Sugar, Hemoglobin A1c, Apolipoprotein B, Apolipoprotein AI and Malondialdehyde in Type 2 Diabetic Patients. Iranian journal of pharmaceutical research: IJPR. 2015;14(1):131.

165. Mozaffari-Khosravi H, Talaei B, Jalali B-A, Najarzadeh A, Mozayan MR. The effect of ginger powder supplementation on insulin resistance and glycemic indices in patients with Type 2 diabetes: A randomized, double-blind, placebo-controlled trial.
Complement Ther Med. 2014;22(1):9-16.

166. Virtanen KA, Lönnroth P, Parkkola R, Peltoniemi P, Asola M, Viljanen T, et al. Glucose uptake and perfusion in subcutaneous and visceral adipose tissue during insulin stimulation in nonobese and obese humans. J Clin Endocrinol Metab. 2002;87(8):3902-10.

167. Kabon B, Nagele A, Reddy D, Eagon C, Fleshman JW, Sessler DI, et al. Obesity decreases perioperative tissue oxygenation. Anesthesiology. 2004;100(2):274.

168. Fleischmann E, Kurz A, Niedermayr M, Schebesta K, Kimberger $\mathrm{O}$, Sessler DI, et al. Tissue oxygenation in obese and non-obese patients during laparoscopy. Obes Surg. 2005;15(6):813-9.

169. Pasarica M, Sereda OR, Redman LM, Albarado DC, Hymel DT, Roan LE, et al. Reduced adipose tissue oxygenation in human obesity evidence for rarefaction, macrophage chemotaxis, and inflammation without an angiogenic response. Diabetes. 2009;58(3):718-25.

170. Klimova T, Chandel N. Mitochondrial complex III regulates hypoxic activation of HIF. Cell Death Differ. 2008;15(4):660-6.

171. Wang B, Wood IS, Trayhurn P. Dysregulation of the expression and secretion of inflammation-related adipokines by hypoxia in human adipocytes. P Pflugers Arch. 2007;455(3):479-92.

172. Ye J, Gao Z, Yin J, He Q. Hypoxia is a potential risk factor for chronic inflammation and adiponectin reduction in adipose tissue of ob/ob and dietary obese mice. Am J Physiol Endocrinol Metab. 2007;293(4):E1118-E28

173. Hosogai N, Fukuhara A, Oshima K, Miyata Y, Tanaka S, Segawa $\mathrm{K}$, et al. Adipose tissue hypoxia in obesity and its impact on adipocytokine dysregulation. Diabetes. 2007;56(4):901-11.

174. Rausch M, Weisberg S, Vardhana P, Tortoriello D. Obesity in $\mathrm{C} 57 \mathrm{BL} / 6 \mathrm{~J}$ mice is characterized by adipose tissue hypoxia and cytotoxic T-cell infiltration. Int J Obes. 2007;32(3):451-63.

175. Burke B, Giannoudis A, Corke KP, Gill D, Wells M, ZieglerHeitbrock L, et al. Hypoxia-induced gene expression in human macrophages: implications for ischemic tissues and hypoxiaregulated gene therapy. Am J Pathol. 2003;163(4):1233-43.

176. Zeyda M, Stulnig TM. Adipose tissue macrophages. Immunol Lett. 2007;112(2):61-7.

177. Wu H, Ghosh S, Dai Perrard X, Feng L, Garcia GE, Perrard JL, et al. T-cell accumulation and regulated on activation, normal $\mathrm{T}$ cell expressed and secreted upregulation in adipose tissue in obesity. Circulation. 2007;115(8):1029-38.

178. Rocha VZ, Folco EJ, Sukhova G, Shimizu K, Gotsman I, Vernon $\mathrm{AH}$, et al. Interferon- $\gamma$, a Th1 Cytokine, Regulates Fat Inflammation A Role for Adaptive Immunity in Obesity. Circ Res. 2008;103(5):467-76.

179. Kintscher U, Hartge M, Hess K, Foryst-Ludwig A, Clemenz M, Wabitsch $\mathrm{M}$, et al. T-lymphocyte Infiltration in Visceral Adipose Tissue A Primary Event in Adipose Tissue Inflammation and the Development of Obesity-Mediated Insulin Resistance. Arterioscler Thromb Vasc Biol. 2008;28(7):1304-10.

180. Liu J, Divoux A, Sun J, Zhang J, Clement K, Glickman JN, et al. Genetic deficiency and pharmacological stabilization of mast cells reduce diet-induced obesity and diabetes in mice. Nat Med. 2009;15(8):940-5.

181. Nishimura S, Manabe I, Nagasaki M, Eto K, Yamashita H, Ohsugi $\mathrm{M}$, et al. CD8+ effector T cells contribute to macrophage recruitment and adipose tissue inflammation in obesity. Nat Med. 2009;15(8):914-20.

182. Ohmura K, Ishimori N, Ohmura Y, Tokuhara S, Nozawa A, Horii $\mathrm{S}$, et al. Natural killer $\mathrm{T}$ cells are involved in adipose tissues inflammation and glucose intolerance in diet-induced obese mice. Arterioscler Thromb Vasc Biol. 2010;30(2):193-9.

183. Panunti B, Fonseca V. Effects of PPAR gamma agonists on cardiovascular function in obese, non-diabetic patients. Vasc Pharmacol. 2006;45(1):29-35.

184. Sozio MS, Lu C, Zeng Y, Liangpunsakul S, Crabb DW. Activated AMPK inhibits PPAR-\{alpha $\}$ and PPAR-\{gamma $\}$ transcriptional activity in hepatoma cells. Am J Physiol Gastrointest Liver Physiol. 2011;301(4):G739-47.

185. Varga T, Czimmerer Z, Nagy L. PPARs are a unique set of fatty acid regulated transcription factors controlling both lipid metabolism and inflammation. Biochim Biophys Acta -Molecular Basis of Disease. 2011;1812(8):1007-22

186. Matthews CP, Colburn NH, Young MR. AP-1 a target for cancer prevention. Curr Cancer Drug Targets. 2007;7(4):317-24.

187. Lee YH, Giraud J, Davis RJ, White MF. c-Jun N-terminal kinase 
(JNK) mediates feedback inhibition of the insulin signaling cascade. J Biol Chem. 2003;278(5):2896-902.

188. Melnik BC, John SM, Schmitz G. Over-stimulation of insulin/IGF1 signaling by western diet may promote diseases of civilization: lessons learnt from laron syndrome. Nutr Metab (Lond). 2011;8(1):41.

189. Cheng Z, White MF. Targeting Forkhead box O1 from the concept to metabolic diseases: lessons from mouse models. Antioxid Redox Signal. 2011;14(4):649-61.

190. Salih DA, Brunet A. FoxO transcription factors in the maintenance of cellular homeostasis during aging. Curr Opin Cell Biol. 2008;20(2):126-36

191. Dormandy JA, Charbonnel B, Eckland DJ, Erdmann E, MassiBenedetti M, Moules IK, et al. Secondary prevention of macrovascular events in patients withType 2 diabetes in the PROactive Study (PROspective pioglitAzone Clinical Trial In macroVascular Events): a randomised controlled trial. Lancet. 2005;366(9493):1279-89.

192. Lubet RA, Fischer SM, Steele VE, Juliana MM, Desmond R, Grubbs CJ. Rosiglitazone, a PPAR gamma agonist: Potent promoter of hydroxybutyl (butyl) nitrosamine-induced urinary bladder cancers. Int J Cancer . 2008;123(10):2254-9.

193. Lewis JD, Ferrara A, Peng T, Hedderson M, Bilker WB, Quesenberry CP, et al. Risk of bladder cancer among diabetic patients treated with pioglitazone interim report of a longitudinal cohort study. Diabetes care. 2011;34(4):916-22.

194. Brownlee M. Biochemistry and molecular cell biology of diabetic complications. Nature. 2001;414(6865):813-20.

195. Amiot MJ, Riva C, Vinet A. Effects of dietary polyphenols on metabolic syndrome features in humans: a systematic review. Obes Rev. 2016;17:573-586. 